\title{
Protection and Revealing of Traditional Settlements and Cultural Assets, as a Tool for Sustainable Development: The Case of Kythera Island in Greece
}

\author{
Anastasia Vythoulka ${ }^{1}$, Ekaterini T. Delegou ${ }^{1, * \mathbb{D}}$, Costas Caradimas $^{2}$ and Antonia Moropoulou ${ }^{1}$ \\ 1 School of Chemical Engineering, Zografou Campus, National Technical University of Athens (NTUA), \\ 9 Iroon Polytechniou Str., 15780 Athens, Greece; anastasia_vi06@hotmail.com (A.V.); \\ amoropul@central.ntua.gr (A.M.) \\ 2 School of Architecture, Patision Campus, National Technical University of Athens (NTUA), \\ 42 Tositsa \& Patision Str., 10682 Athens, Greece; ccara@arch.ntua.gr \\ * Correspondence: edelegou@central.ntua.gr
}

check for updates

Citation: Vythoulka, A.; Delegou, E.T.; Caradimas, C.; Moropoulou, A. Protection and Revealing of Traditional Settlements and Cultural Assets, as a Tool for Sustainable Development: The Case of Kythera Island in Greece. Land 2021, 10, 1324. https://doi.org/10.3390/land10121324

Academic Editor: Manuel Pulido Fernádez

Received: 26 October 2021

Accepted: 24 November 2021

Published: 1 December 2021

Publisher's Note: MDPI stays neutral with regard to jurisdictional claims in published maps and institutional affiliations.

Copyright: (c) 2021 by the authors. Licensee MDPI, Basel, Switzerland. This article is an open access article distributed under the terms and conditions of the Creative Commons Attribution (CC BY) license (https:/ / creativecommons.org/licenses/by/ $4.0 /)$.

\begin{abstract}
Preserving and highlighting cultural heritage is directly related to sustainable development. The adaptive reuse of cultural heritage buildings and traditional settlements can be a core issue in the implementation of a circular economy strategy, especially in remote areas. In this framework, the current study focuses on Kythera, an isolated Greek island. For the analysis of the study area, research in local archives and communication with the municipality and local stakeholders was conducted, while questionnaires addressed to Kythera's residents and visitors were developed and processed. Thus, both the special features of the island and the needs of the local community were identified, leading to the proposal of three adaptive reuse schemes at a different scale and within a different management model. The first scheme is focused on the institution of "Eghorios Periousia" and proposes the adaptive reuse of the island's English Schools as focal points for the promotion of Kythera's identity. The second scheme focuses on the smaller declared traditional settlements and proposes the adaptive reuse of their housing stock as an affordable permanent residence solution. The third scheme focuses on the abandoned neighborhood of Mavrogiorgiannika in the traditional settlement of Karavas and proposes its adaptive reuse as agritourism accommodation facilities.
\end{abstract}

Keywords: remote areas development; island development; Eghorios Periousia; heritage management; adaptive reuse; circular economy; PPP; public-private partnership

\section{Introduction}

The objects of cultural heritage protection and revealing consist of a multi-scale variety of assets, from individual monuments to historical complexes and areas. The notion of cultural heritage, tangible and intangible, involves not only monuments of significant historical value but also rural constructions, human practices and traditions [1]. Thus, the case of traditional settlements protection and revealing is a multifactor issue consisting of technical, historical and social aspects. The contribution of local communities living in such historic environments is crucial since the purpose of the protection of traditional settlements does not only include the preservation of their buildings, but also the prosperity of their residents [2]. Thus, the "living heritage approach" is based on the prerequisite that people and heritage are inseparable. According to ICCROM, living heritage includes all "places that continue to perform the function for which they were originally created". More specifically, it aims at preserving the original use of a place's tangible and intangible heritage while ensuring its connection with the local community [3,4]. Subsequently, in traditional rural settlements, the preservation of agricultural heritage could contribute to social cohesion, ensuring environmental balance and rural development [5].

Preservation and revealing of cultural heritage assets is a core element of sustainable development plans providing environmental, economic and social benefits via adaptive 
reuse [6]. Environmental, since reuse is a "profitable" solution in energy consumption terms; economic, since revealing projects attract external economies to the area of their implementation and social, since cultural heritage can provide educational, symbiotic and cooperative values to the local communities $[7,8]$.

The importance of highlighting cultural heritage in terms of sustainable development is especially significant in remote areas and even more so on islands. According to the report of the ESPON program (EPSON: European Observation Network for Territorial Development and Cohesion, program entitled "The Development of the Islands - European Islands and Cohesion Policy"), the management of cultural and natural assets is a core issue for islands' sustainable development plans, since the high density of natural and cultural assets, and the strong cultural identity are two of the most important strengths of island communities $[9,10]$.

The purpose of this work is the protection and revealing of the traditional settlements and cultural assets of Kythera in a circular economy framework, aiming to enhance the island's sustainability potential. Analysis of the study area was conducted through research of the island's archives and communication with local stakeholders, combined with in situ observations and the use of questionnaires addressed to the residents and visitors of Kythera. After determining the island's weaknesses and potentials, three different schemes of adaptive reuse at different scales were suggested. The aim of the proposals was to enhance the island's potential while minimizing the impact of its weaknesses through the adaptive reuse of Kythera's cultural heritage. In this process, the unique institution of "Eghorios Periousia", according to which the cultural and environmental assets of the island and every building or area with no registered owner consist of inter-communal property of all the Kytherians, was determinant.

\section{Background and Literature Review}

\subsection{Cultural Heritage Protection: Traditional Settlements}

One of the basic principles of the Venice Charter (1964) is related to the definition of the notion "historic monument," expanding it from building scale to area scale. Thus, the notion of a historic monument includes not only the individual monument but also its surroundings, which reflect the historical context under which it was created. The "World Heritage Convention" in Paris (1972) inserted the spatial dimension of the protection of cultural heritage and the "Charter of Amsterdam" (1975), the "Granada Convention" (1985) and the "Charter on the Conservation of Historic Towns and Urban Areas" in Washington, inserted the notion of "historic complex" [1]. Traditional settlements, a subcategory of historical complexes, were described as part of Greek cultural heritage in the Greek Constitution enactment (1975). The first definition of the term "traditional settlement" was described in the Granada Convention, which was adopted by the Greek State in 1992 (Law 2039/1992) [11]. According to this document, a traditional settlement is "an urban or rural homogeneous buildings complex with interesting architectural, structural, social, or historical features in need of protection due to their unique and valuable character." In the Archeological Law of 2002 (Law 3028/2002) [12] traditional settlements are considered as "collective human activity sites" or "historical sites" with "traditional, ethnological, social, architectural, industrial, historical or scientific significance" that must be preserved [13]. The typology configuration of traditional settlements could be based on geographical, geo-morphological and spatial criteria [14]. Thus, the process of revealing and preserving a traditional settlement demands a multifactor study per case, taking into consideration various aspects from the residents' everyday life to the sustainability of the historic complex.

\subsection{Sustainable Development and Management of Cultural Heritage}

The Council of Europe has defined the relationship between heritage and sustainable development in all its dimensions, mainly in two conventions, the "European Landscape Convention" of 2000 (full integration of the environmental, cultural, social and economic dimen- 
sions in a single and comprehensive way, which is their application throughout the region [15]) and the "Framework of the Convention on the Value of Cultural Heritage for Society in Faro in 2005" (the values and potential of cultural heritage must be used as a source for sustainable development and quality of life in an ever-evolving society [16]). According to the Policy Statement of the 4th UCLG World Summit "Culture as the Fourth Pillar of Sustainable Development" [17], "the promotion of culture in sustainable development can be achieved by developing the cultural sector itself (heritage, creativity, cultural industry, cultural tourism, crafts), as well as insuring that culture has the place it deserves in all policies, especially those related to education, the economy, science, communication, the environment, social cohesion and international cooperation." In March 2021, Europa Nostra, in collaboration with ICOMOS, published the 'European Cultural Heritage Green Paper', setting Europe's common heritage at the heart of the European Green Agreement, as "the future survival of Europe's cultural heritage and the success of the European Union's Green Agreement are connected and interdependent objectives" [18]. All the above-mentioned references underline the important contribution of cultural heritage to the overall plans for sustainable development, both directly and indirectly. Directly, through reuse values that meet demand and supply, and indirectly, through relational values, which are the foundation of symbiotic processes and in turn create additional economic, social and environmental values [9].

The term 'sustainable management' for cultural heritage has been included in the Operational Guidelines for the Implementation of the World Heritage Convention since 2005 as a guide for the management of World Heritage Sites. It emphasizes the constructive role of cultural heritage in promoting human development, which in the long run will lead to an improvement in the sustainability of world heritage itself [19]. According to Perry and Gordon, the most effective approach to understanding and managing cultural heritage is through resilience, adaptability, and transformability [20]. Cultural heritage management is directly related to the economic viability of monuments. Today, the aim of sustainable cultural heritage versus the cultural heritage museum requires the activation of the public sector in order to highlight the direct and indirect positive effects of conservation. According to Pikard, "it is important for local governments and other stakeholders to create strategic studies on the management and use of cultural heritage" [19]. Additionally, the tourism sector is directly related to the process and aim of highlighting the cultural and natural characteristics of each region; however, if not implemented in a specific framework, this pursuit can be either a great opportunity for cultural heritage or a danger to its preservation. Therefore, the pursuit of a model for sustainable tourism is related to the formation of a multifactor model for the overall protection and reveal of cultural heritage. An interdisciplinary approach is necessary for the determination of the proposing development model, the involvement of the various stakeholders and the integration of cultural heritage in overall spatial planning [21-23].

\subsection{Adaptive Reuse of Cultural Heritage in Relation to Circular Economy and Sustainability}

Globally, many cities are beginning to realize that the reuse of cultural heritage buildings is a core issue of overall revealing programs [24], since historic cities have assets of cultural and economic value with high growth potential in a sustainable perspective [25]. According to the general framework proposed within the Horizon 2020 "CLIC" project, "cultural heritage adaptive reuse could be seen as an entry point to circular cities implementation, avoiding the 'waste' of resources by reusing and regenerating buildings and sites which present functional obsolescence, and thus lost their original functionality" $[9,26]$. In these terms, the concept of "continuity" in heritage preservation is implied in the aim 'to give the cultural and natural heritage a function in the life of the community' [6]. Adaptive reuse of cultural heritage could provide both environmental, economic and social benefits to the local communities $[8,27,28]$. According to Foster, "studies on individual, reused heritage buildings and meta-analyses, find significant reductions in energy consumption and related carbon dioxide and other greenhouse gas emissions, fossil fuel consumption, freshwater consumption, and materials use" [23,29], making adaptive reuse an ecological 
decision. As far as it concerns the economic aspect of adaptive reuse, an area's cultural assets could serve as an important economic capital for regional financial growth, providing new points of touristic interest, job opportunities for the local community and important assets for the municipal government [30]. The social aspect of adaptive cultural reuse does not refer to the materialistic values of the cultural assets but to their contribution to the well-being of the local communities by providing a sense of belonging, creating favorable living conditions, mitigating excessive urbanization and adapting to climate change [30]. Such a multispectral matter demands an interdisciplinary approach involving the local community and stakeholders in order to achieve the most beneficial results (economical, environmental and social) [28].

\section{Methodology}

The aim of this work was the protection and revealing of traditional settlements and cultural assets of the Greek isolated island of Kythera, in the context of circular economy and sustainability. Based on an extensive literature review on the contribution of cultural assets preservation to sustainable development, a specific methodology was developed with distinct objectives and interrelated phases (Figure 1) focused on the real case scenario of Kythera. Analysis of the study area started with the bibliographic review of data available in the island's archives, in order to define Kythera's special features. The municipality of Kythera and local stakeholders, such as "Eghorios Periousia" and the Kythera Foundation for Culture and Development, were approached in order to contribute to the analysis.

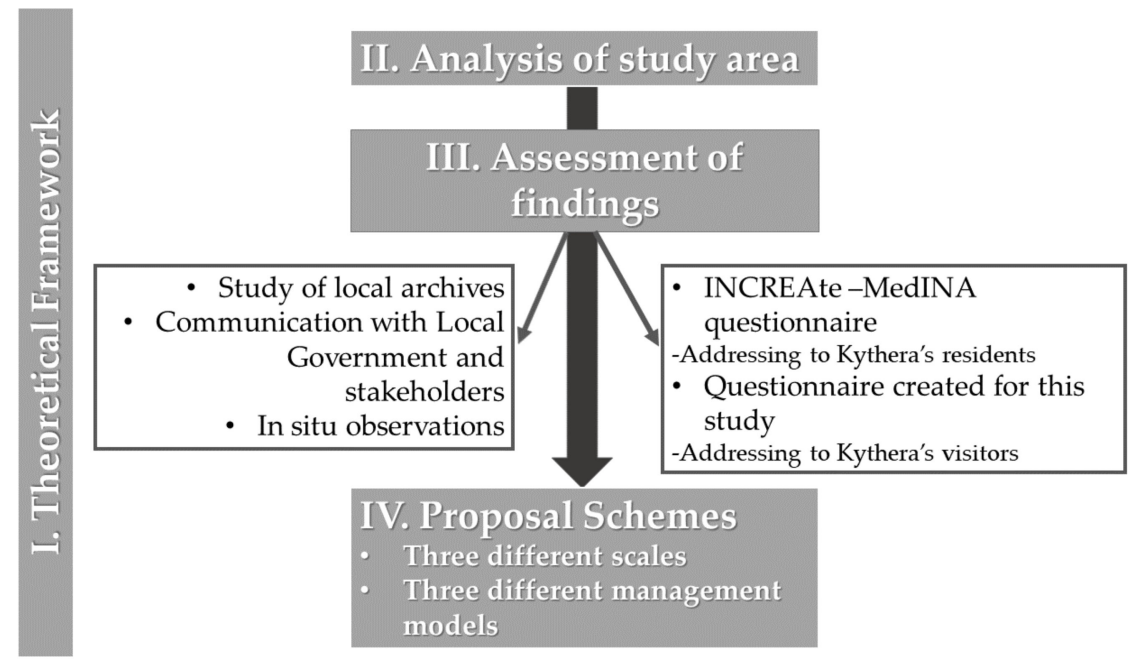

Figure 1. The methodology of the study.

Subsequently, the opinions of Kythera's residents and visitors regarding the island's development prospects were integrated into the analysis of the study area. The results of the questionnaire "Recording and Evaluation of Cultural Characteristics of Kythera and Antikythera", conducted by the Mediterranean Institute for Nature and Anthropos (MedINA, a Greek nongovernmental organization) during the INCREAte project 2016 [31-33], were processed, in order to capture the residents' point of view. The MedINA questionnaire consisted of thirty structured interviews of Kythera's residents of different ages and professions. Additionally, a questionnaire addressed to Greek visitors of the island was created for the purposes of this study. Thirty-four participants completed the questionnaire anonymously, in order to create a similar sample to the MedINA questionnaire. The questionnaire was structured in three sections: the first had to do with general information, the second, with the sights of Kythera, and in the third section, the final impression of the visitors from their stay in Kythera, was recorded. The questions were of "closed response" type and "short development" type so that the collected data could be processed in a more 
objective and structured way, as well as to ensure the adequate participation of Kythera's visitors. The application "Google forms" was used for the formulation of the questionnaire, as well as for the collection and processing of data. The questionnaire was distributed via social media profiles and pages related to Kythera, due to strict regulations in force regarding in-person contact during the COVID19 pandemic.

The assessment of findings was based on the literature review, as well as on the island's potentials for sustainable development. Subsequently, three different schemes of adaptive reuse at different scales were suggested, in order to address the needs of the residents by capitalizing the impact of the island's cultural heritage. The data used for the investigation of the study area and proposal schemes formulation were obtained from local archives (municipal reports, maps of Kythera, drawings of public buildings), and from the Hellenic Military Geographical Service (updated orthophotos of the study area). Figures, apart from photos, were created in CAD, illustrating the findings of the study.

\section{Analysis of Study Area}

\subsection{The Case Study of Kythera Island}

Kythera is the most southern island of the Ionian Islands, located opposite Cape Maleas of the Peloponnese (Figure 2). It is a unique case of a Greek island due to a series of geographical and historical individualities. The first inhabitants of the island were Minoans, followed by Athenians and Spartans [34]. During the Roman and Byzantine years, the island was in decline and later abandoned. Subsequently, various natural disasters, in combination with pirate raids led to the desolation of the island and then to its resettlement by new inhabitants, mainly from Monemvasia (Peloponnese) and the island of Crete [34]. After the 18th century, French, Venetian and British occupiers passed through the island, leaving their mark on the formation of its cultural identity. In 1815, the "Great Powers" of the time recognized the "United States of the Ionian Islands", including Kythera. Nevertheless, England kept the Ionian Islands under its protection (commission) until 21 May 1864, when the islands became part of the Greek State. In 1941, Kythera was occupied by the Axis forces until it was liberated on 4 September 1944 [35].

Due to Kythera's turbulent history, the cultural reserve of the island is rich and wide-ranged. Since the first archaeological excavation in Manitochori of Kythera in 1915, 4 castles have been discovered and/or studied adequately, a cave with indications of the symbolic use of the Late Bronze Age, a citadel of the Classical Age, dozens of temples of the Byzantine and post-Byzantine period, neoclassical palaces, places of interest in war history and 17 temples located from the period of British rule [34,36]. The medieval monuments of Kythera are of particular interest as they are well preserved and consist of important attractions. The four castles of the island are located in Paliochora, the former capital of the island that was abandoned after pirate raids, in Chora, in Kato Chora and in Avlemonas. The location of the Castles (Paliochora and Avlemonas in the south, Kato Chora in the west and Chora in the south) was crucial in Medieval times in order to protect the island from the frequent pirate raids. Especially in Chora and Kato Chora, fortification constructions were maintained by the Venetian occupiers of Kythera, thus protecting the core of the inhabited settlements until the late 19th century [37]. The Venetian occupation had an important impact on the island; a number of settlements were created, and remarkable buildings, castles and churches (i.e., Kato Chora Fortress) were constructed [37]. During the period of British rule, the foundation was laid for the construction of public infrastructure that is still functional today (Road network, English Schools). Another consignment of Kythera's British occupiers was the educational system. During British rule, education was obligatory for the boys of the island. The school buildings of this period form a significant category of monuments in Kythera [37]. The so-called "English Schools" of the island are located in Milapidea, Potamos and Kato Chora (Figures 3 and 4). They are one-room buildings of characteristic gothic architecture, with arched windows and vaulted ceilings in Milapidea and Kato Chora, following simplified English architectural forms. The school 
building in Potamos has a slate roof and a roughcast exterior, following the form of local northern Kythera architecture.

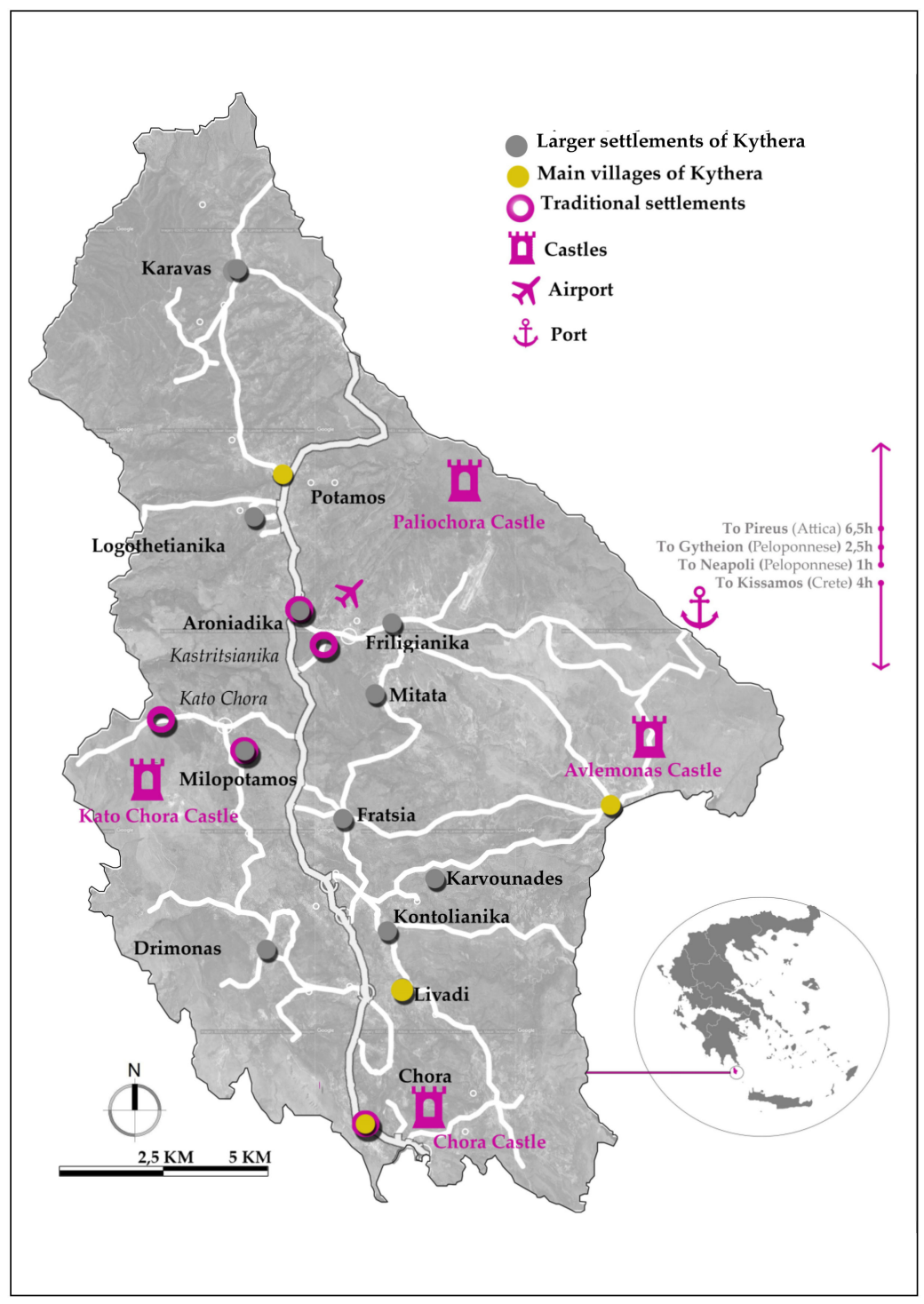

Figure 2. The map of Kythera.

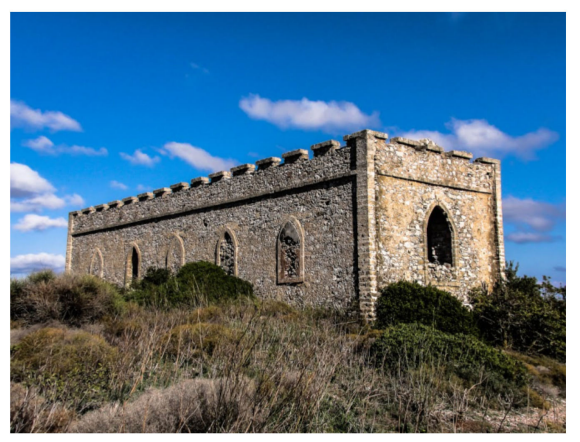

Figure 3. The English School of Milapidea in Kythera. 


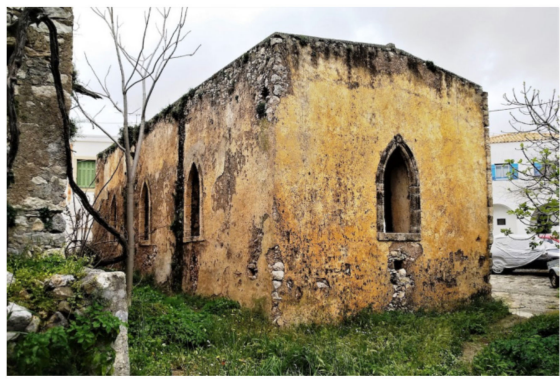

(a)

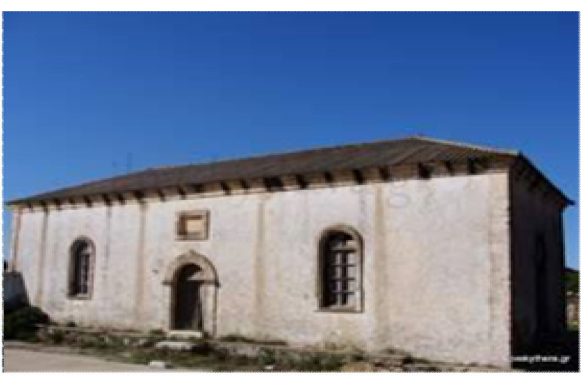

(b)

Figure 4. (a) The English School of Kato Chora, (b) The English School of Potamos in Kythera, Greece.

Kythera also has a large number of settlements. Within the census of 1889, a total of 87 settlements appear on the island of Kythera [31]. Today Kythera has a total of 62 inhabited settlements, most of which are located inland. The development of the residential network of Kythera is elongated, following the central plateau and the main road axis, with a few extensions relating to the existence of springs or agricultural land. The structure of Kythera's residential network was influenced and formed by the frequent pirate raids and by the western feudal system. A "polycentric" system of spatial organization characterizes the island, according to which Chora is the main administrative and commercial center; however, it is not the only one. In the northern part of the island, the center is the village of Potamos, in the western part is Mylopotamos, and in the eastern part is Avlemonas [38]. Among the settlements of the island, five of them are under a special protection framework by the Greek Ministry of Culture: Chora, Mylopotamos, Kato Chora, Aroniadika and Kastritsianika. Chora, as the capital of the island, is the most prominent traditional settlement. The settlement was developed on three uphill roads, starting from the Castle, and is characterized by dense construction and a lack of public spaces. Mylopotamos (Figure 5a), is one of the most popular settlements of the island, because of the waterfall and the overall natural landscape. A river crosses the village, which is organized into three residential entities. Kato Chora (Figure 5b) is a small settlement next to Mylopotamos. The center of Kato Chora is at the entrance of the Venetian Castle, which is at the core of the settlements. Aroniadika (Figure 6a) is one of the oldest rural settlements of the island. Building development follows the main road axis and the northern part of the village is the oldest area, with densely built houses and a lack of public spaces. Finally, Kastritsianika (Figure $6 \mathrm{~b}$ ) is a small rural village with roughly 100 houses and 40 residents. The settlement was also developed across the main road, organized into five neighborhoods.

The traditional architecture of the island is not homogeneous. A first distinction is based on geographical criteria-in the north of Kythera, the architectural elements are similar to those in the Peloponnese (Figure 7a), whereas, in the south, the local architecture has influences from Crete and the other Aegean islands (Figure 7b) [36]. Accordingly, in the northern settlements, roofs are canted and covered with tiles whilst in southern settlements, ceilings are constructed with domes, covered by flat roofs. The architecture developed in Kythera is also characterized by simplified elements of Venetian and English architecture, mainly in public buildings. Another interesting distinction of the local architecture is the fortress construction, imposed by the danger of the frequent pirate raids that characterizes the strategically located settlements [39]. Additionally, the housing stock of the island varies, depending on the social status of the property owners. Mansions, mainly located in Chora and Potamos, are influenced by Venetian architecture. They are two-storey buildings with external stairs that lead to the upper floor, where the main living spaces are located. Windows and doors are small, decorated with stone made crests and decorative elements. Folksy houses are simpler, mainly one-storey buildings. The main construction materials used in the island are wood and stone, while the typical decorative elements are the ornate chimneys and the louloudieres, that is built flower beds under the windows [40]. 


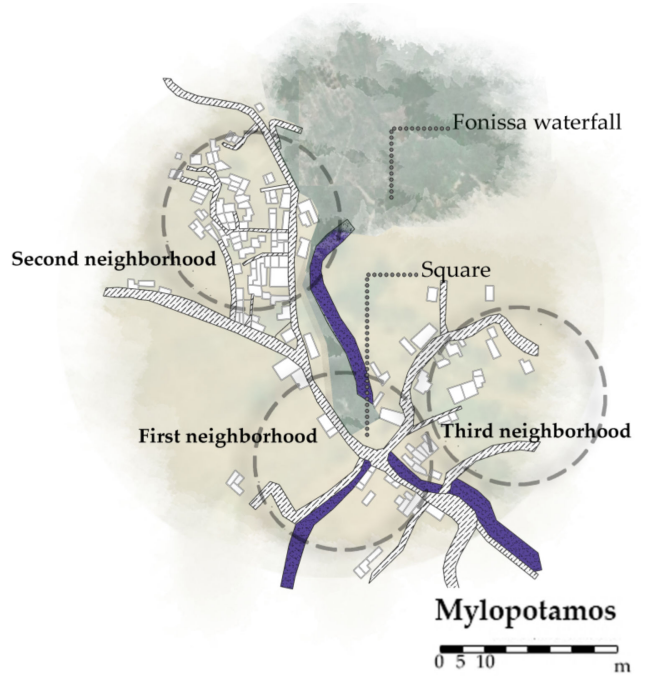

(a)

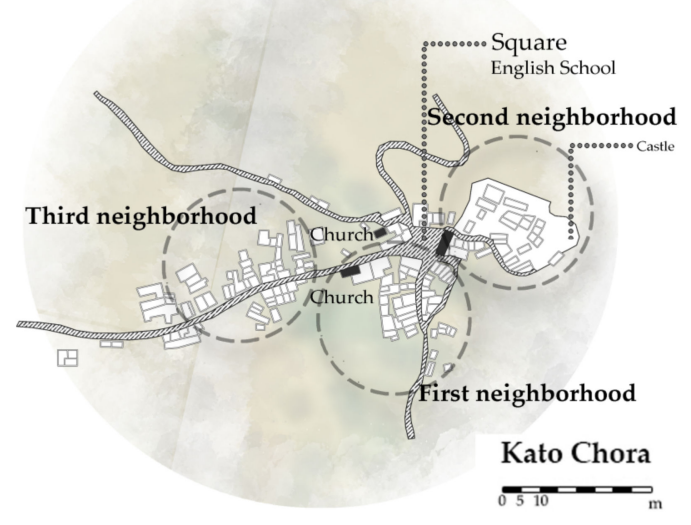

(b)

Figure 5. Spatial organization of (a) Mylopotamos, (b) Kato Chora.

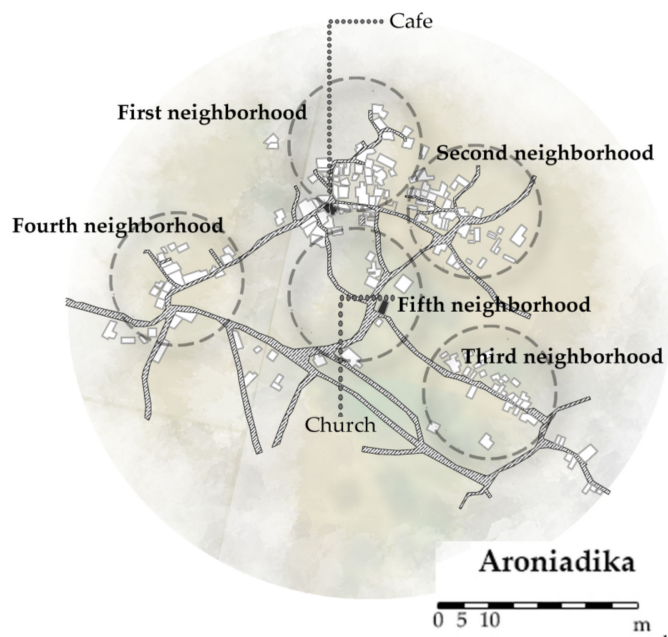

(a)

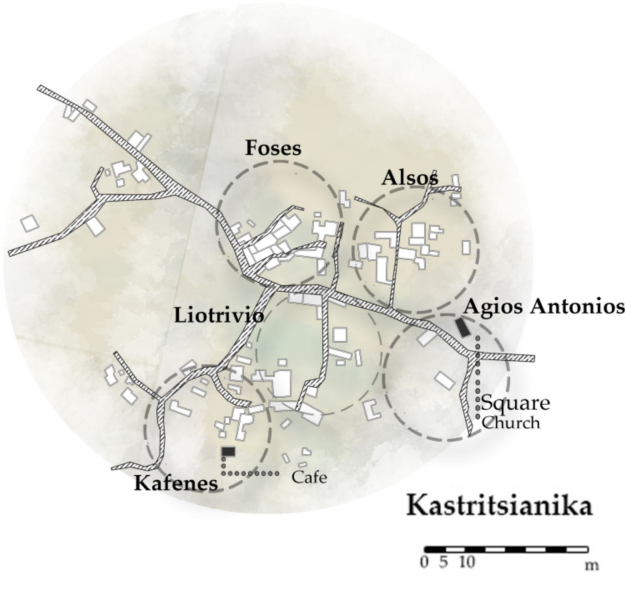

(b)

Figure 6. Spatial organization of (a) Aroniadika and (b) Kastritsianika.

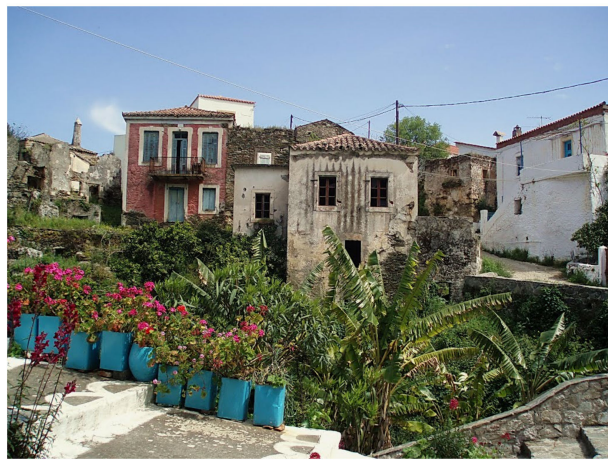

(a)

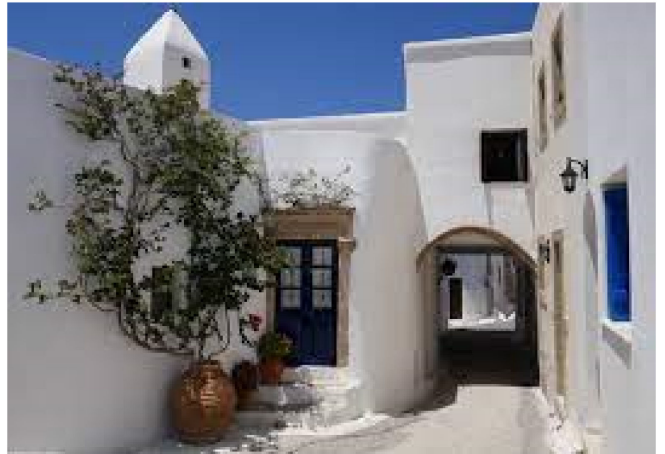

(b)

Figure 7. (a) Potamos (northern Kythera) and (b) Kato Chora (southern Kythera).

Another interesting originality of Kythera refers to the island's unique system of public

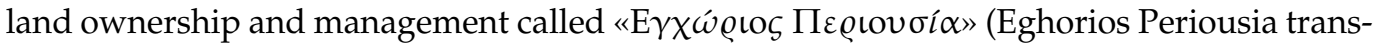


lated as Domestic Wealth Board or Inland Property). The existence of this original system of land ownership was established when the State of the Ionian Islands (Kythera among them) was an English protectorate (1815 to 1864). Since the protectorate was administered on federal principles, public land was regarded not as the legal property of the central government, but as that of each individual island. In 1864, Kythera and the other Ionian Islands were ceded to Greece, where according to Greek case law, public land, monuments and buildings, or areas with unknown ownership, are considered the legal property of the central government. However, under the unification law of 1866, the Eghorios Periousia status of the Ionian Islands was recognised by the central Greek government, pending individual legislation for each of the seven islands. Such legislation, distributing the public land to new municipalities or regions, was passed for most of the islands—but not for Kythera, Antikythera, Ithaka and Paxoi [41]. According to this law, 'Eghorios Periousia of Kythera and Antikythera" was confirmed as the "direct, exclusive and uncontested owner of all real property of whatever nature found on Kythera and Antikythera which is not demonstrably the property of individuals, [including] abandoned land, mountains, woods, the shoreline and foreshore, uninhabited islets, the entirety of the movable and real property of the Holy Pilgrimages [Monasteries] and in general every form of real estate which in other parts of the state would be regarded as Public [i.e., state owned] [37]. The status was confirmed by the Law on Forestry Land of 1979 (N.998/1979). Further legislation in 1984 clarified that the 'Eghorios Periousia of Kythera and Antikythera' "is the intercommunal property of local authorities on Kythera and Antikythera", thereby formally conferring ownership and control of public land on the islands to the local communes through elected representatives. A presidential decree $(138 / 2004)$ and the so-called Kallikratis administrative reform law of 2010 (N.3852/2010) specify that 'Eghorios Periousia of Kythera and Antikythera' constitutes a Legal Public Entity that continues exerting its functions according to the relevant special legislation [41]. According to Eleni Leontsini, "although the Eghorios Periousia of Kythera and Antikythera today is mainly economic, the theoretical framework that defines it refers to communitarian forms and is an example of communal administration where citizens actively participate in local representative administration" [42]. Therefore, residents have the power to decide on matters relating to intracommunity property and to promote its protection. An important problem in the operation of the institution is the absence of the systematic recording of these assets. Unfortunately, the only source for quantitative and qualitative determination of Eghorios Periousia property is still the "Land Registry of 1803", since the Final Greek Land Registry is not yet completed [37].

Today, the total permanent population of the Municipality of Kythera amounts to approximately 3900 residents, mainly occupied in agriculture and tourism [38]. However, the forecasts for the demographic situation of Kythera and Antikythera are not auspicious. The decrease and aging of the local population may intensify, mainly due to seasonal employment and residence, isolation and problematic inland transport, in combination with the general phenomenon of abandonment of the province that is observed throughout Greece [43]. According to the strategic plan of the Municipality of Kythera, tourism of the island is characterized as small-scaled, with regulated development, providing a variety of activities and emphasizing on gaining experiences from the local culture and the preservation of traditional values [38]. The issue related to tourism in Kythera arises from the short duration of the tourism season and the reduced employment opportunities for seasonal workers during the winter. In the problems related to the local economy, the report of the municipality mentions the high percentage of the economically inactive population, the small scope of business activity and the insufficient use of comparative advantages, such as tourism and culture. The most important possibility that is pointed out, is the management of the cultural reserve for the implementation of special sectoral policies, especially in relation to tourism [43]. Residents and local organizations in Kythera are very active, promoting projects of cultural and natural heritage revealing. "Kythera Trails" among them was a project aiming to reveal the island's cultural and natural assets by restoring the traditional paths of Kythera. Kythera Trails involve eleven thematic 
routes and provide a popular activity for the visitors of the island [44]. Local cultural organizations and residents' initiatives are also centered on the preservation of the island's rural constructions such as watermills, arrogation canals and anavathmides, a traditional system of retaining walls for the organization of farming land [45].

\subsection{Investigation of the Opinions of Kythera's Residents and Visitors about the Island's Development Prospects}

In the framework of the MedINA INCREAte project, during the summer of 2016, a series of structured interviews with the residents of Kythera were conducted in order to identify the problems of the island. Thirty residents from various settlements of the island of different ages and professions were interviewed (Figure 8) [35].
1. How would you describe the island in three words?
2. What are you proud of about your island?
3. What would you change on the island?
4. Do you think that life in Kythera is better now than some years ago?
5 . Tell us about your work (in relation to nature-culture issues).
6. Can you select three favorite areas on the map and justify your choices?
7. Can you select three problem areas on the map and to justify your choices?
8. If you left the island forever, what would you take with you (material or intangible)?

Figure 8. The questions of the constructed interviews with the residents of Kythera presented in the MedINA INCREAte project [35].

In the question about the elements that residents are proud of, the most popular answer is "the natural and cultural environment", followed by "people" and "mild tourism development". When asked about the changes that the residents would make, the vast majority referred to the "mentality of the locals" (the way Kythera's residents behave and think). An important issue that many residents mentioned is the lack of transport, either at a local level or the connection with the rest of Greece, the lack of protection measurements for the natural and cultural environment and the composition of the population, where more visitors are recorded comparing to the permanent residents. The majority of respondents are engaged in agriculture and tourism. Their vision described "a green island with developing organic farming ('finding and implementing new funding programs'), quality local products and mild tourism connected to the social fabric ('creation of open archeological parks, further utilization and revealing of the cultural assets of Kythera', etc.)". Residents employed in tourism reported that the island offers quality but high-cost holidays and that one of the biggest problems is the small duration of the tourist period.

Mylopotamos came first among the favorite areas of Kythera because of the special man-made and natural landscape, followed by Chora and Paliochora due to their historical interest and Karavas due to its landscape and traditional architecture. Most residents' choices were based on the beauty of the natural environment, while for a quarter of respondents, the criterion was the area's cultural legacy.

In an attempt to describe Kythera as a tourist destination, a questionnaire addressing the island's visitors was conducted for the purposes of this study, and it was answered by 34 respondents. The questionnaire was structured in three sections: the first section had to do with general information, the second with the sights of Kythera and the information that the visitors had before their arrival on the island; while in the third section, the final impressions of the visitors from their stay in Kythera, were recorded (Figure 9). 
1st Section_General Information

1. What is your age?

2.Which mean of transport and route did you select?

3. Are you a regular visitor of the island?

4.When did you go in Kythera?

5 . What was the duration of your trip?

6. What was the concept of your trip?

7. Did you have a mean of transport?

8. Do you think a private mean of transport is necessary in Kythera?

9.Where did you stay?

10.Which was your accomodation?

2nd Section_Sights of interest in Kythera

1. Did you have any information about Kythera's traditional settlements before your trip?

2. During your stay, which traditional settlements impressed you and why?

3. During your stay, which traditional settlements disappointed you and why?

4. Did you have any information about Kythera's monuments before your trip?

5 . During your stay, which monument impressed you and why?

6. Which elements of the Kytherian trandition impressed you?

7. Did you visit any sites of natural interest? Which elements of the environment impressed you?

8.Which is your opinion about Kythera's traditional architecture?

9. Which landmarks and gathering points impressed you? 3rd Section_Final impressions

Which was your impression about Kythera's environment,

ments, settlements, tradition?

are the problems you indicate in the island?

Which are general impressions and comments about Kythera?

4. Would you visit Kythera again?

Figure 9. The questions addressed to the visitors of Kythera.

In the age group 18-24 belong six respondents (17.6\%), fourteen in group 25-34 $(41.2 \%)$, three in group 35-44 (8.8\%), one in group 45-54, seven in group 55-64 (20.6\%) and three in the age group 65 and over (8.8\%) (Figure 10a). Twenty of the respondents arrived from the port of Neapoli (Peloponnese) (58.8\%), ten from the port of Piraeus (Attica) (29.4\%), two from the port of Gythio (Peloponnese) and two arrived by plane from Athens $(5.9 \%)$. Nineteen of them are regular visitors to the island $(55.9 \%)$, while fifteen visited Kythera only once $(44.1 \%)$ (Figure $10 \mathrm{~b})$. Thirty-two visited the island during summer $(94.1 \%)$, while two during spring (5.9\%). Twelve respondents stayed in Kythera for more than 15 days (35.3\%), four stayed up to14 days (11.8\%), seventeen up to 7 days (50\%) and one up to $3(2.9 \%)$ (Figure 11a). Fourteen of the respondents visited the island with friends (41.2\%), twelve with their family (35.3\%) and eight with their partner (25.3\%). Twenty-nine had a private means of transportation (85.3\%), while five did not (14.7\%) when everyone considered the existence of a means of necessary transportation.

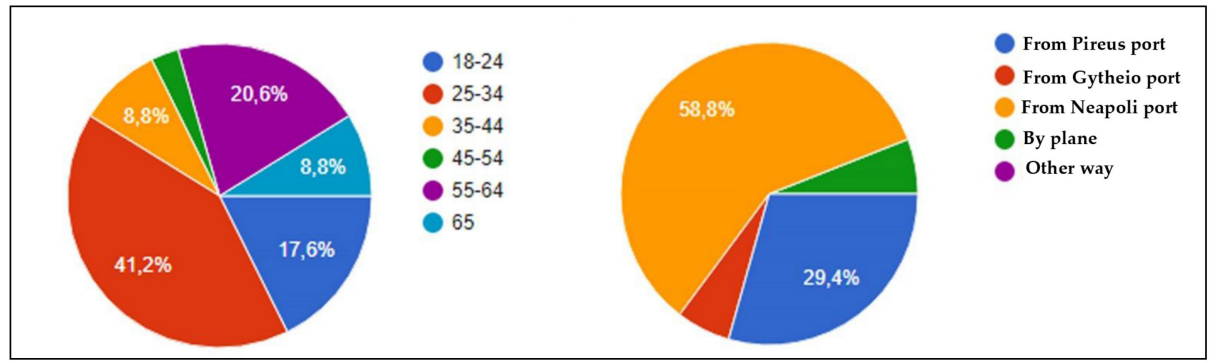

(a)

(b)

Figure 10. Pie diagrams of (a) the ages of the participants (b) the way they arrived to Kythera.

As for the settlements they chose, four visitors stayed in Chora, Drymonas, Potamos, Livadi and Karavas, two in Sparagareio and Avlemonas, three in Platia Ammos and one in Agia Pelagia. Eighteen stayed in a private house (52.9\%), six in rented rooms (17.6\%), five in a hotel $(14.7 \%)$ and five were camping (Figure $11 \mathrm{~b})$. Most of the respondents were impressed by Chora, Mylopotamos, Avlemonas and the northern villages, while the majority had not been informed before travelling to the island about any of the traditional settlements. The villages that mainly disappointed the visitors were Livadi, Diakofti and Agia Pelagia, due to the intense touristic development, while roughly half of the respondents were not disappointed by any of Kythera's villages. Most of the respondents had not heard of any of the monuments, while the more well-informed visitors had 
heard about the Castles of Chora and Paliochora and the waterfalls of Mylopotamos. Among the monuments mentioned were the castles of Chora and Kato Chora, the various monasteries, in addition to the lighthouse of Moudari and Paliochora. As for elements of tradition, the most mentioned are the festivals and the local kitchens. Additionally, the respondents noted the willingness of residents to keep elements of their intangible cultural heritage in their everyday life. The most widespread sights of natural beauty were the waterfalls in Mylopotamos, the beaches and the alternation of vegetation of the island. Regarding the architecture, most visitors noticed the difference between the north (influences from the traditional architecture of the Peloponnese) and the south (influences from the traditional architecture of Crete and the Aegean islands), as well as the good preservation of architectural elements, especially in non-coastal settlements. As for the landmarks, the majority mentioned the Castles, the springs in Karavas, the Moudari Lighthouse and the square of Potamos.

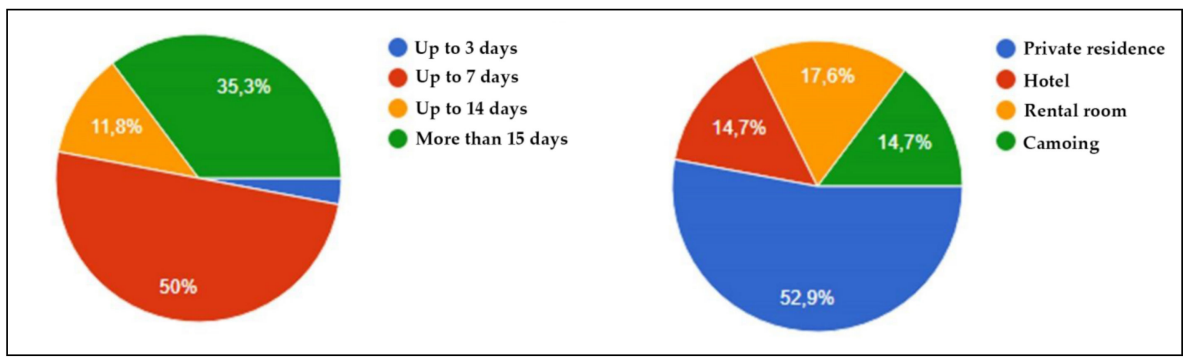

(a)

(b)

Figure 11. Pie diagrams of (a) the duration of the participant's stay in Kythera and (b) the accommodation they used during their stay.

Almost all the visitors were very impressed by the natural environment, quite impressed by the monuments and villages, neutral about the tradition and satisfied by the mentality of the residents (Figure 12). All respondents noted the bad road network and the lack of local transport as a problem, while some of them mentioned the difficulty of going to the island during the non-summer months. The majority of the respondents referred to Kythera as an island for a "calm vacation", which takes several days to be explored. On the positive side, most of them referred to the "mild tourism development" (meaning not mass tourism development) in most settlements, while all of the respondents but one would like to visit Kythera again.

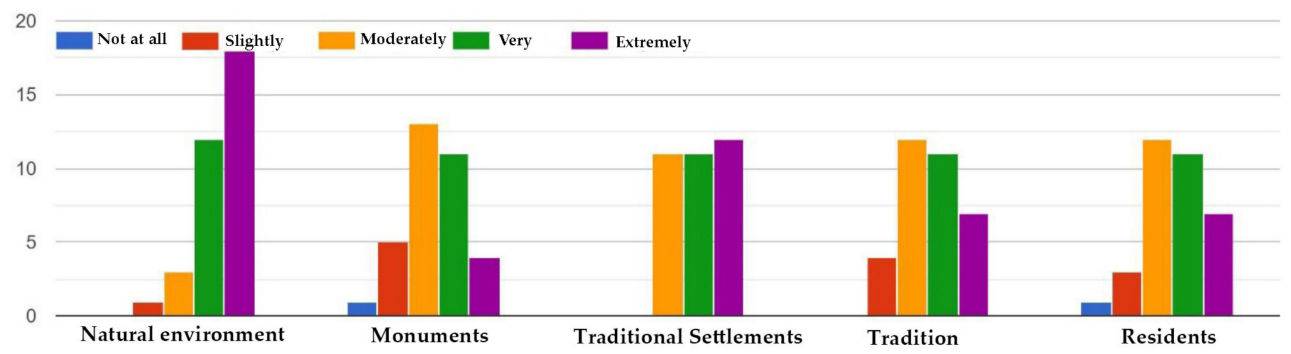

Figure 12. Bar diagram of the evaluation of the participants about Kythera's natural environment, monuments, traditional settlements, tradition and residents.

Kythera's residents are proud of the cultural and environmental reserve of their island, expressing concerns about the lack of sufficient protection and revealing framework. They agree with the mild tourism development while pursuing the elongation of the touristic period. Their main concerns are the decrease of young permanent residents, the low level of involvement in organic farming, the problems regarding transportation and accessibility and the insufficient updating and cooperation at a local level. From the visitors' 
point of view, the cultural and natural environment of Kythera is remarkable, combined with the mild tourism development. They also point out the problems referring to local transportation and accessibility.

Additionally, the answers in the questionnaire of the visitors offered information about the profile of Kythera's tourism. The first conclusion was the fact that the island consists of a destination for various age groups and vacation scenarios (Figure 11). The accommodation chosen varied as well, while the traditional settlements, apart from Chora and Mylopotamos, were not widely known. The variety of monuments was also not observed since the visitors referred only to the most prominent historic constructions (the castles) and natural beauty sites (waterfalls). Another interesting observation was the fact that the northern villages, which are less developed in terms of tourism, seem to attract the interest of the visitors, due to their architecture and natural environment.

\section{Assessment of Findings-Issues to Be Addressed and Potentials for the Sustainable Development of Kythera}

The assessment of Kythera's analysis findings were based on the literature review, as well as the island's potential for sustainable development. The intention was to avoid mass tourism in a remote, underdeveloped island while meeting the needs of its residents for economic growth and more favorable living conditions. Taking into consideration the fact that a per case analysis is important in order to set the basis of a sustainable regional development plan [22], the special features of Kythera and the opinions of Kythera's residents and visitors about the island's development prospects were systematically investigated.

For the sustainable development of the island, Kythera's special features in terms of history and cultural reserve, spatial organization, traditional architecture, social organization and demography were examined, and are summarized in Table 1. Kythera, due to the island's history, has a diverse cultural reserve and a lot of, yet un-exploited, cultural assets (English Schools). There is a large number of settlements on the island and a noticeable distinction between the southern and the northern settlements; northern settlements are less promoted and developed, while they present a different but characteristic architectural style compared to the southern settlements. In terms of social organization, the existence of Eghorios Periousia proves the inter-communal tradition of Kythera's residents. Finally, the population of the island is aging and decreasing over time.

Table 1. Findings of study area analysis regarding Kythera's special features.

\begin{tabular}{cc}
\hline Elements & Observations \\
\hline History and monuments & Diverse cultural reserve, unexploited assets \\
Spatial organization & Large number of settlements, less promoted northern settlements \\
Traditional architecture & Diverse architectural elements \\
Social organization & Inter-communal management tradition (Eghorios Periousia) \\
Demography & Decreasing, aging population \\
\hline
\end{tabular}

The observations of Kythera's residents and visitors regarding the island's character are related to Kythera's special features (Table 2). The natural environment of the island, but also the man-made, consist of valuable assets for the development of Kythera. The fact that the initiatives of residents and local bodies are already focused on the preservation of these assets is particularly promising. The "Kythera Trails" network contributes to the promotion of the natural environment and cultural reserve of the island. At the same time, the multi-center residential organization of the island offers the possibility of a multicenter development, avoiding mass tourism models. In addition, the turbulent history of Kythera left a variety of monuments and architectural forms on the island that coexist, creating different and multiple points of interest. Finally, the existence of the institution of Eghorios Periousia could be beneficial for the development of the island. Eghorios Periousia framework permits the locals to be directly involved in processes that ensure the 
preservation of natural and cultural assets while creating economic growth opportunities for them.

Table 2. Evaluation of Kythera's elements according to their residents and visitors.

\begin{tabular}{cll}
\hline Elements & Evaluation & Indicator \\
\hline Cultural reserve & positive & Residents and visitors \\
Natural environment & positive & Residents and visitors \\
Mild tourism development & positive & Residents and visitors \\
Local transportation & negative & Residents and visitors \\
Accessibility & negative & Residents and visitors \\
Decrease of permanent residents & negative & Residents \\
Duration of touristic season & negative & Residents \\
Sufficient involvement with organic farming & negative & Residents \\
Updating and cooperation & negative & Residents
\end{tabular}

On the other hand, several issues should be addressed in order to ensure the island's overall sustainable development. Special spatial studies of the island, as well as a cohesive protection framework for traditional settlements, are crucial for the preservation of Kythera's built heritage. Only five of the traditional settlements on the island (Chora, Mylopotamos, Kato Chora, Aroniadika, Kastritsianika) are under a protection framework by the Greek Ministry of Culture, laying the responsibility of traditional heritage protection on the sensibility of the residents and local government. A lot of monuments and traditional settlements are not well promoted, especially in the northern part of Kythera, depriving local communities of various benefits that could be achieved from their revealing and growth. Additionally, the lack of a Land Registry holds back the cultural preservation initiatives on the island. The management of the abandoned housing stock of the island, due to the migratory flows of the past years, is also an important issue, especially within traditional settlements. Another important issue in Kythera is the lack of affordable accommodation opportunities for permanent residence. In these terms, Kythera does not form an appealing environment neither for semi-permanent residents (teachers, doctors) nor for new, permanent residents. Transportation, both across the island and in terms of its connection with the rest of Greece, is also a big problem since it sets Kythera as an inaccessible destination, difficult to be discovered in its entirety.

\section{Proposal Schemes}

6.1. Adaptive Reuse of Traditional Settlements and Cultural Assets, as a Tool of Sustainable Development of Kythera

After studying Kythera's special features while taking into consideration the residents' needs, the proposal schemes aim to promote the sustainable development of this underdeveloped, remote island. According to the analysis of the study area, the proposals focused on:

- The revealing of the lesser known cultural assets of Kythera

- The management of the large abandoned housing stock

- The enhancement of the less developed northern settlements of the island

Adaptive reuse, a practice referring to the preservation of cultural heritage in terms of circular economy, could provide various economic, environmental and social benefits in this process. The existence of the Eghorios Periousia framework on the island is the driving force of the proposals. It could ensure the enhancement of the local community in adaptive reuse projects that succeed in the preservation of Kythera's cultural and natural assets while promoting the island's economic growth. Apart from Eghorios Periousia, employment sectors of the residents (agriculture and tourism), in combination with their intention to extend the tourism season with mild features, but also the need to attract more permanent residents, could define a proposal based on agritourism. This intention goes hand in hand with visitors' positive opinion about the natural environment of Kythera, 
which is one of the most impressive elements of the island, according to their point of view. Nevertheless, the municipality and the Kythera Institute of Culture and Development are already actively promoting programs related to the development of organic farming and the revealing of the natural environment through the conservation of traditional trails.

The objectives of the proposed interventions were the protection and the revealing of the traditional settlements and the creation of new points of interest, the strengthening of the local economy, and the improvement of the living conditions of the residents. A triple exploitation program is proposed, consisting of three different schemes of adaptive reuse at different scales (Figure 13). The intention to set the island's cultural heritage preservation as the core of a development model that answers to the needs of the residents was on the basis of the proposals. The first scheme refers to the individual buildings of English Schools, owned by Eghorios Periousia, suggesting their use as places of promotion for Kythera's natural environment, intangible cultural heritage and local products. The second scheme refers to the housing stock with no use within the smaller traditional settlements, in order to increase the opportunities for affordable permanent accommodation on the island and reveal the settlements themselves. The third scheme refers to the rehabilitation of an abandoned neighborhood in the less prominent northern Kythera, suggesting its reuse as an agritourism complex.

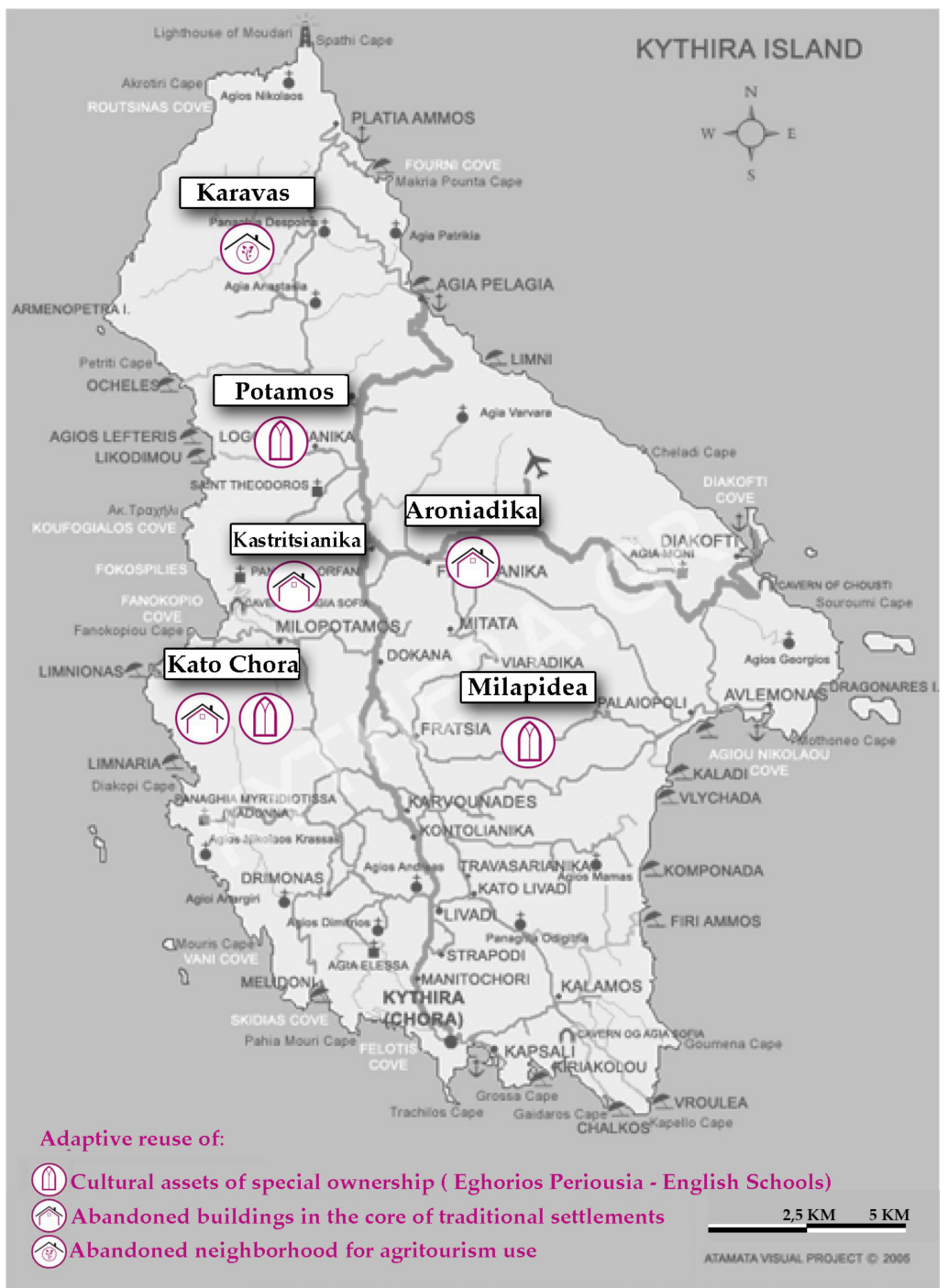

Figure 13. Map of the proposal schemes for the sustainable preservation of traditional settlements and cultural assets according to the principles of circular economy in Kythera, modified after kithira.com. 


\subsection{Proposal Scheme 1: Adaptive Reuse of Cultural Assets of Special Ownership} (Eghorios Periousia-English Schools)

The existence of the institution of Eghorios Periousia in Kythera, beyond its historical interest, can be a driving force for the sustainable development of the island. Structural changes in its mode of operation could contribute to this direction. Kythera has a small population; therefore, the information and decision-making procedures on issues concerning Eghorios Periousia that are essential to the community should have a wide impact on the residents, the local cooperatives and to the cultural associations of the island. Eghorios Periousia as a structure should manage to gain the trust of the islanders, in collaboration with institutions such as KIPA (Kytherian Institute of Culture and Development) that promote cultural promotion activities, proposing solutions and outlets in everyday life problems, and forming the core of the wide participation of the residents. In addition to the necessary recording process, the exemplary revealing of assets belonging to Eghorios Periousia could force individual property owners of the island to preserve and reuse their assets as well.

At the level of actions, it is necessary to arrange contracts among the municipality, Eghorios Periousia, local agricultural cooperatives and investors. These contracts need to be based on the development of sustainable agriculture, in the reapplication of traditional agricultural practices with the maintenance of traditional rural configurations, such as "anavathmides" or the irrigation canals. In this endeavor, the contribution of the individual producers of various products on the island would be decisive. Informative seminars and the exchange of know-how with specialists or residents of other areas who turned to organic farming could help the improvement of production, but also in the establishment of Kythera as a destination of rural interest.

The adaptive reuse scheme regarding Ehgorios Periousia assets focuses on the English Schools that form a significant monumental entity of the island. They comprise identifiable landmarks in Kythera because of their particular architectural form. The suggested new use for each school building is related to its location in relation to the residential fabric. The English School of Milapidea (Figure 14) is in the country of Kythera, skirted by tillable fields (Figure 15). Its use as an agritourism center could be combined with standard experimental cultivations in the surrounding area, promoting local products and traditional rural practices. The English School of Kato Chora (Figure 16) is set in the center of the village, in front of the Castle's entrance (Figure 17). Kato Chora is connected to Mylopotamos, one of the most projected settlements of Kythera, because of its natural environment (Fonissa waterfall), via route M41 on the "Kythera trails" network. Its suggested use is to become a center of nature-oriented activities in order to utilize the existing dynamic of the trail network for the revealing of the settlement of Kato Chora and its cultural assets. Finally, the English School of Potamos (Figure 18) is set within one of the largest settlements of Kythera (Figure 19), the local center of the northern part of the island. Potamos' residents are active in issues related to culture, and the marching band of the island is based there. The use of the English School as a center for the promotion of Kythera's intangible heritage could provide a new point of interest for both the residents and the visitors of the island.

The rehabilitation of the English Schools, which will be funded by European programs (LEADER CLLD) [46], is proposed to be managed by PPPs (public-private partnership), so that the revenues from this intervention could fund other necessary actions of the municipality and Eghorios Periousia. Since English Schools are assets of Eghorios Periousia, their operation will be definitely accessible to the local community. The PPP framework must ensure the compatible restoration of the buildings, the landscaping of their surrounding area and the involvement of the residents during and after the project. 

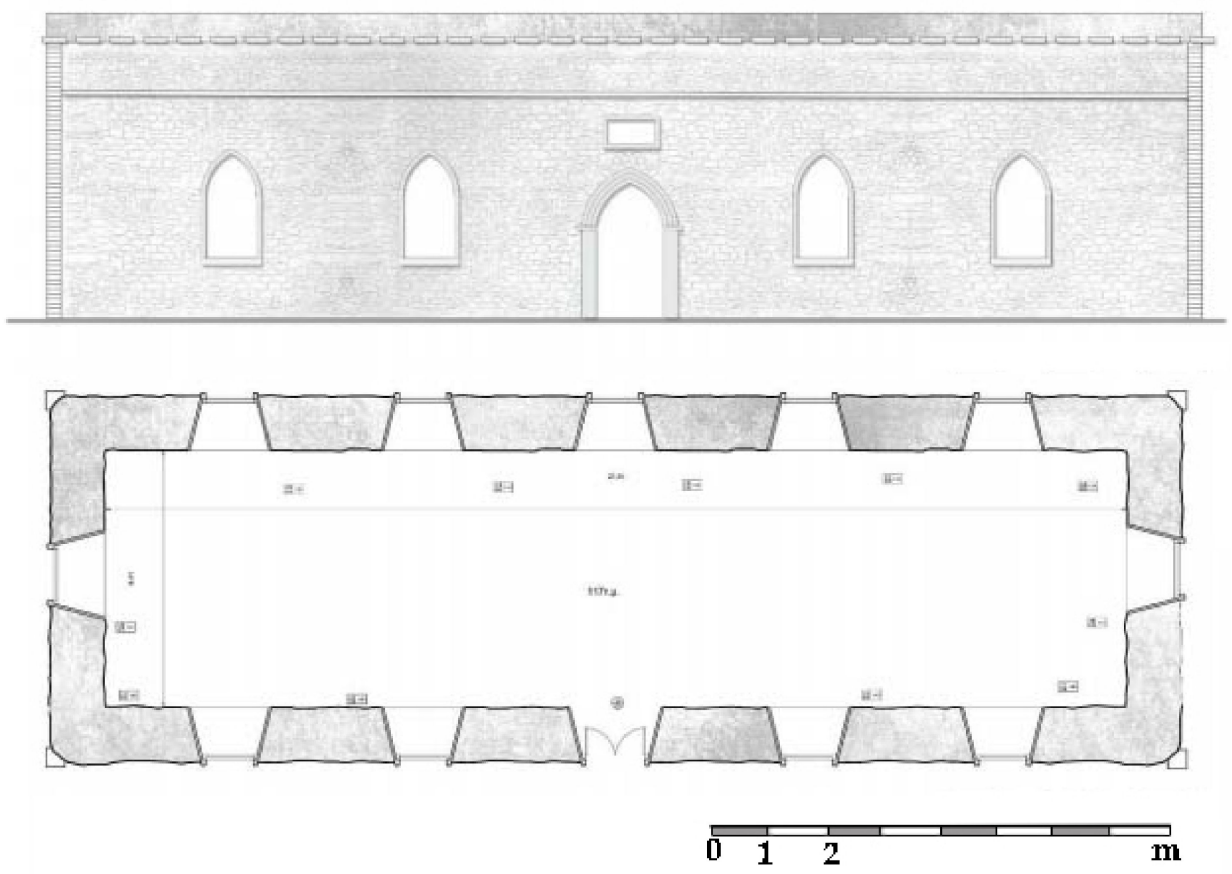

Figure 14. Façade and ground plan of the English School of Milapidea in Kythera, Greece.

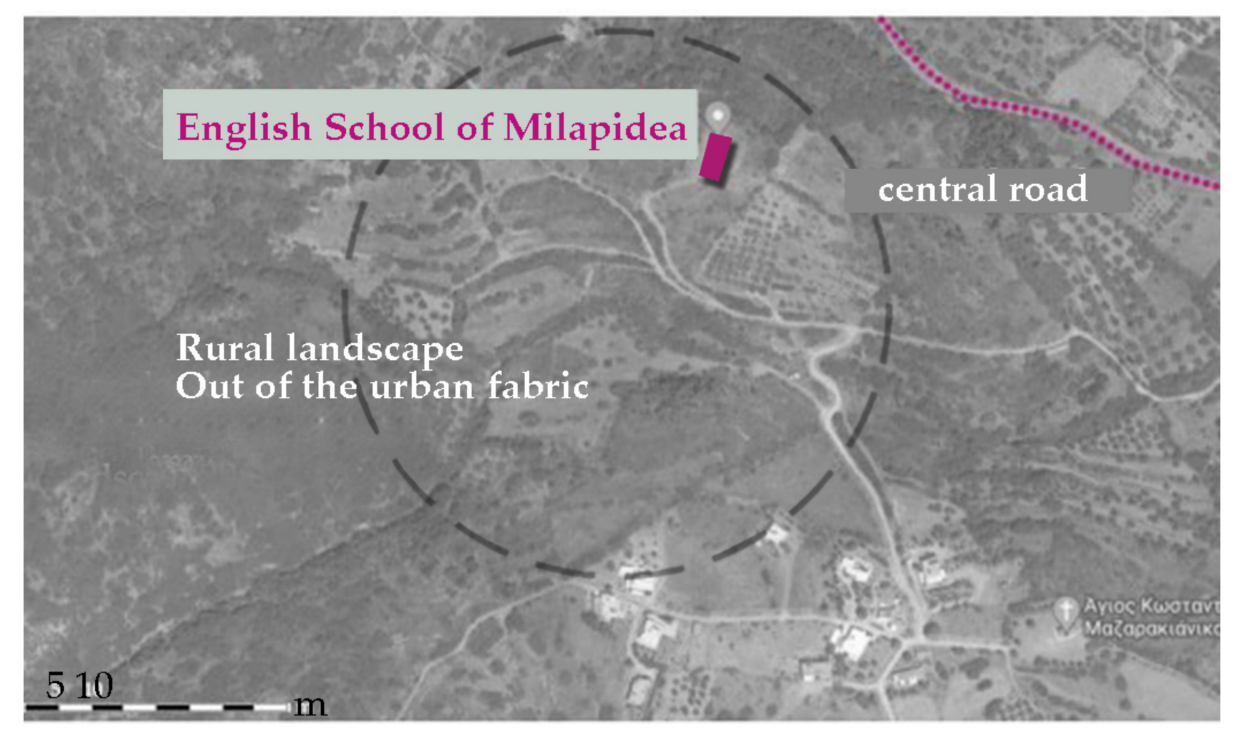

Figure 15. The location of the English School of Milapidea in Kythera, modified after Googlemaps.com. 

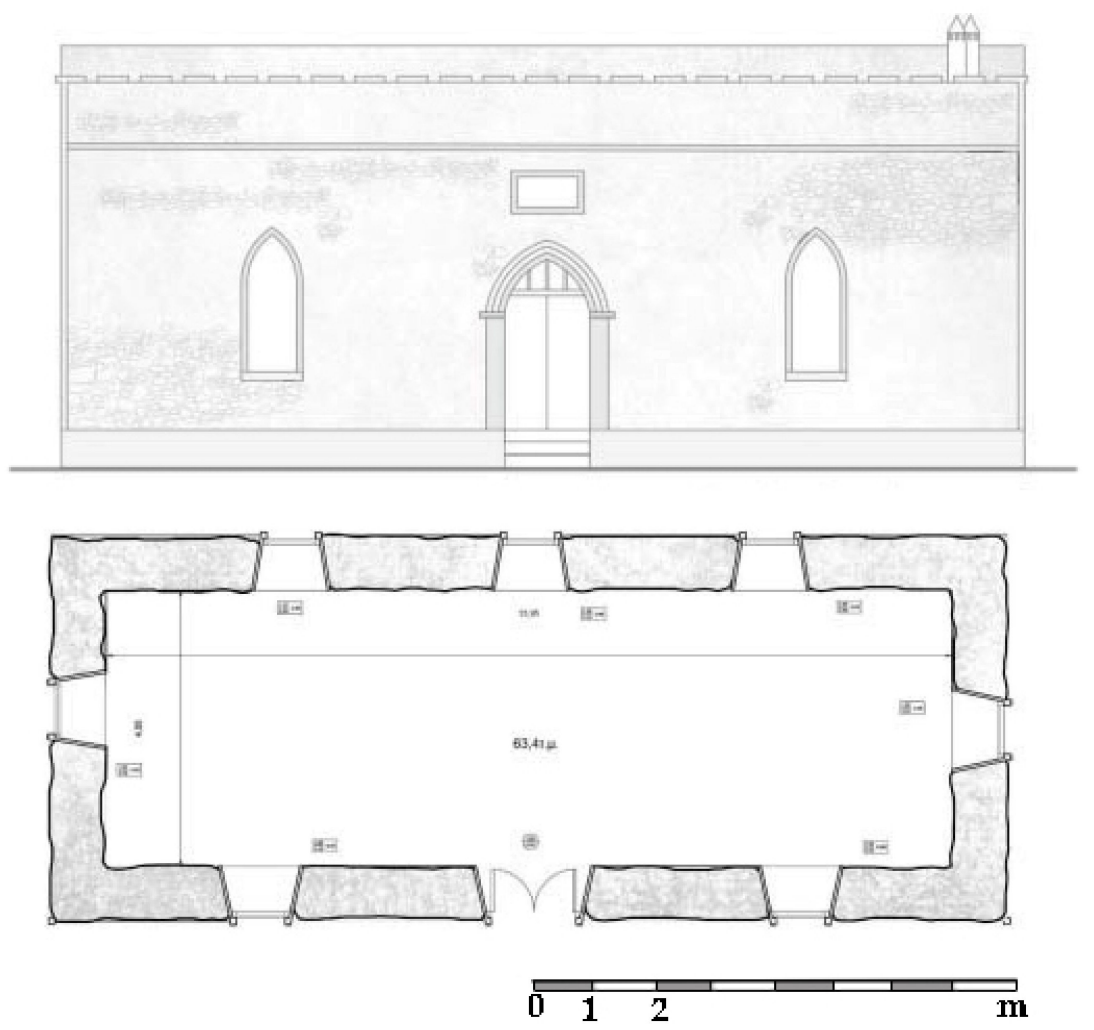

Figure 16. Façade and ground plan of the English School of Kato Chora in Kythera, Greece.

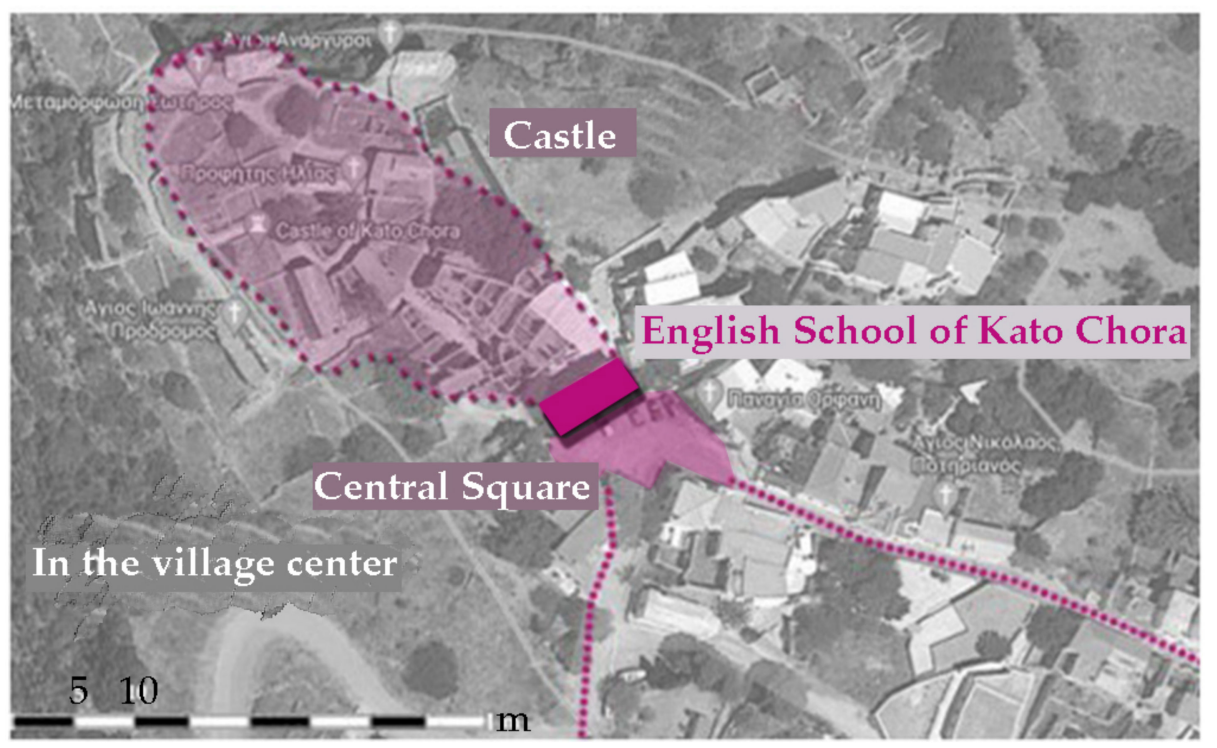

Figure 17. The location of the English School of Kato Chora in Kythera, modified after Googlemaps.com. 

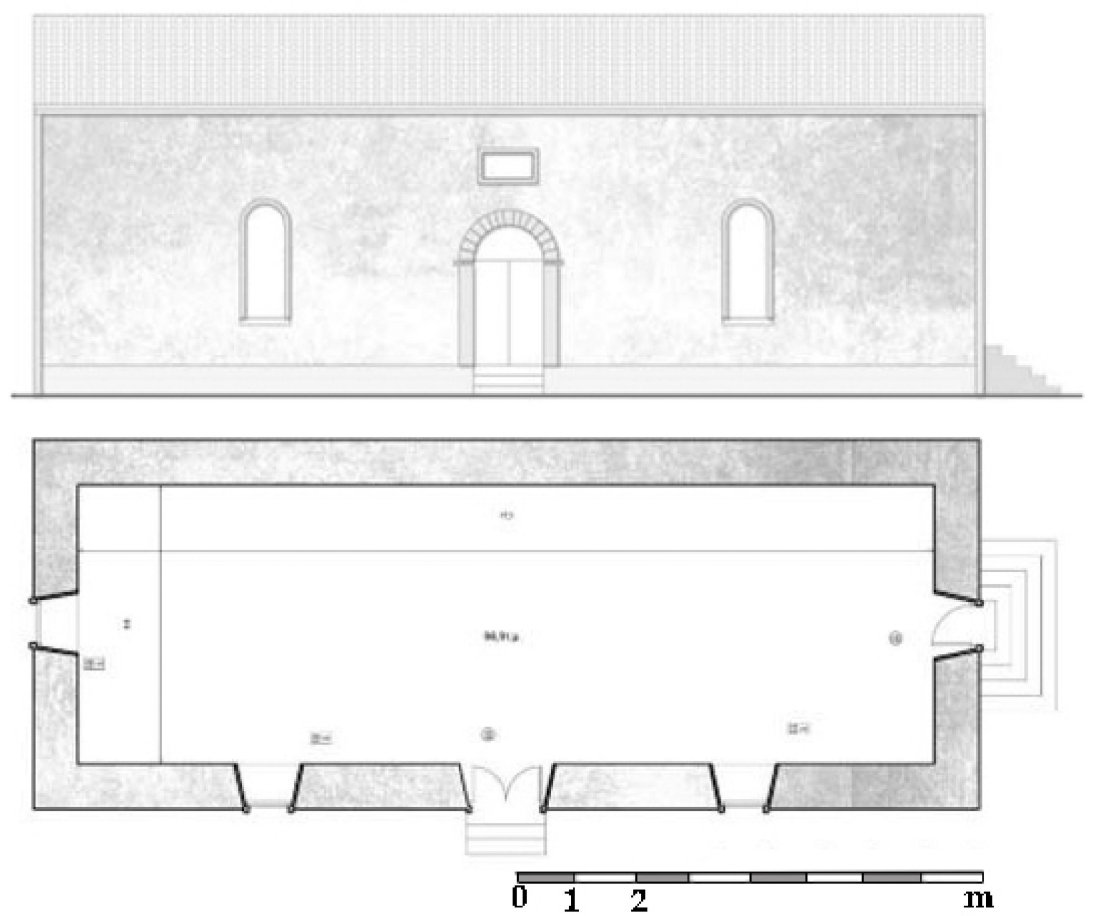

Figure 18. Façade and ground plan of the English School of Potamos in Kythera, Greece.

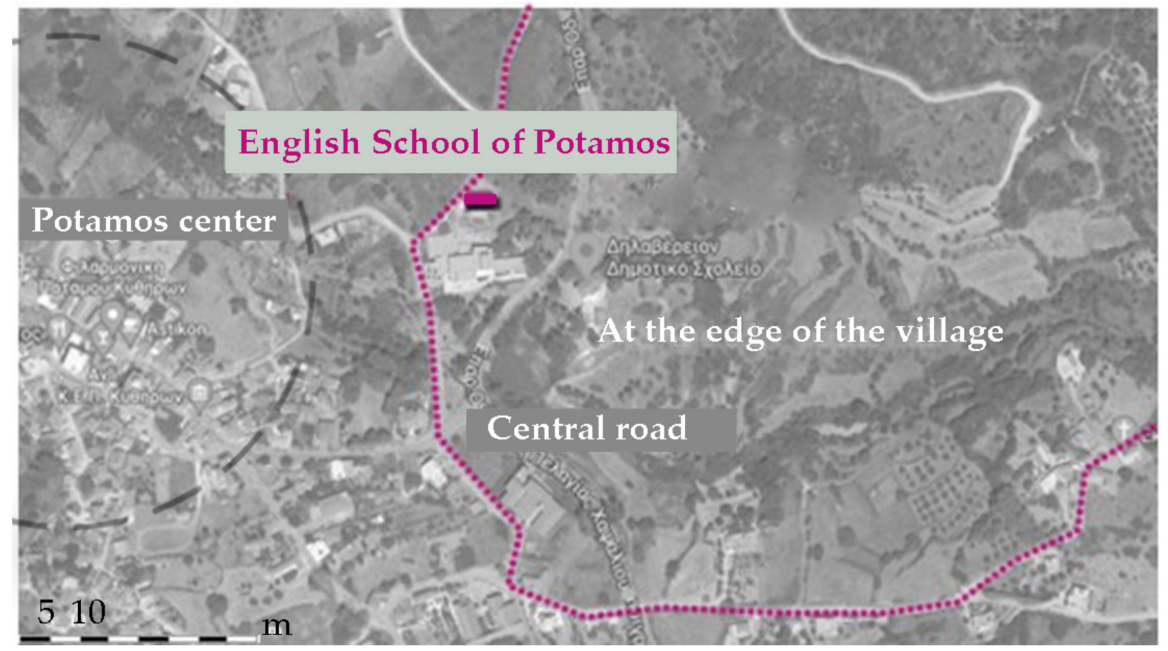

Figure 19. The Location of the English School of Potamos in Kythera, modified after Googlemaps.com.

6.3. Proposal Scheme 2: Adaptive Reuse of Abandoned Buildings in the Core of Traditional Settlements

Among the traditional settlements of Kythera, Chora is the most well known since it accrues the majority of the island's monuments. The villages Mylopotamos (Figure 20a), Kato Chora (Figure 20b), Aroniadika (Figure 21) and Kastritsianika (Figure 22), the four smaller traditional settlements of Kythera, consist of characteristic examples of the local traditional architecture, as mentioned above. They present well-preserved examples of the complex Kytherian architecture, such as rural buildings and constructions (Aroniadika, Kastritsianika), medieval fortress complexes (Kato Chora) and mansions with Venetian influences (Mylopotamos). The four smaller traditional settlements of Kythera are fields of intervention aimed at the overall revealing of the island's traditional architecture (Mylopotamos and Kato Chora), but also for the handling of the lack of affordable residence opportunities in the island (Aroniadika and Kastritsianika). Within the settlements, a lot 
of buildings of cultural interest are abandoned, and due to the lack of a Land Registry in Kythera, their ownership status is unspecified (Figures 23-26). In Mylopotamos, 20.9\% of the housing stock is abandoned, in Kato Chora 37.8\%, in Aroniadika 20.4\%, and in Kastritsianika $42.3 \%$. The recording of the buildings with no use and the clarification of their ownership could be followed by pilot studies of restoration and reuse under the auspices of the municipality and Eghorios Periousia. Priority must be given, apart from the unavoidable tourist exploitation of some of the buildings, in shaping options of affordable housing for the permanent or potential permanent residents of the island, with the aim of revitalizing the settlements themselves through adaptive reuse of their housing stock. Therefore, the goal of adaptive reuse is not the same for all the traditional settlements. Mylopotamos already attracts a large number of visitors because of its special natural environment. Through the trail network of the "Kythera Trails", the highlight could continue to Kato Chora. In this way, the concept of cultural routes in order to reveal a region's cultural assets contributes to the establishment of a sustainable "tourism product" [47-49], especially useful in rural, underdeveloped areas, such as Kythera [50]. The villages of Aroniadika and Kastritsianika, traditionally rural, are already inhabited. Especially in Aroniadika, a lot of traditional buildings have already been restored in order to be used as tourism facilities (Figure 10a). In two vivid traditional settlements, and especially on an island where the finding of a permanent residence is an important issue, tourism as a lever of development should not be the only solution. A portion of the profits from the revealing of English Schools could be allocated to the rehabilitation of the abandoned housing stock of these settlements, in order to preserve the cultural heritage, improve the quality of residents' life and to lay the foundations for the island to be a pole of attraction for young, permanent residents.

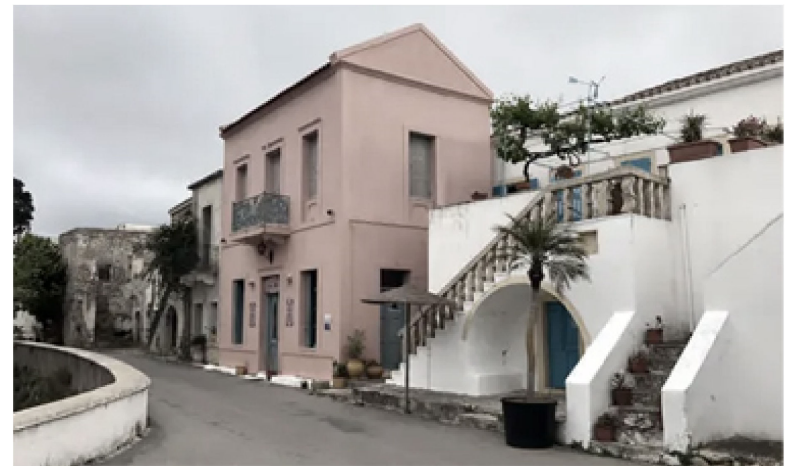

(a)

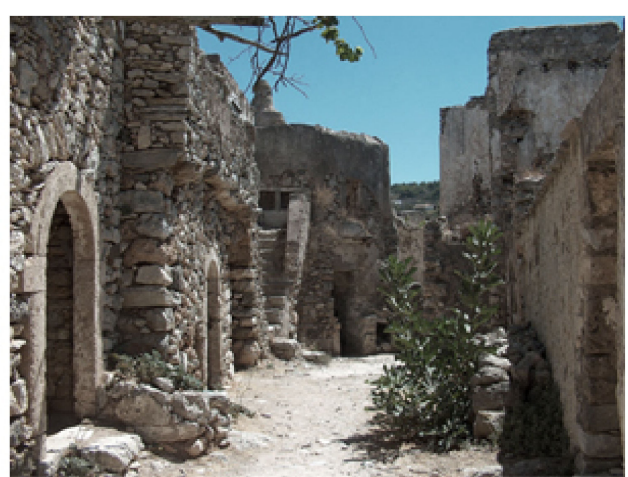

(b)

Figure 20. Mylopotamos (a) and Kato Chora (b) in Kythera.
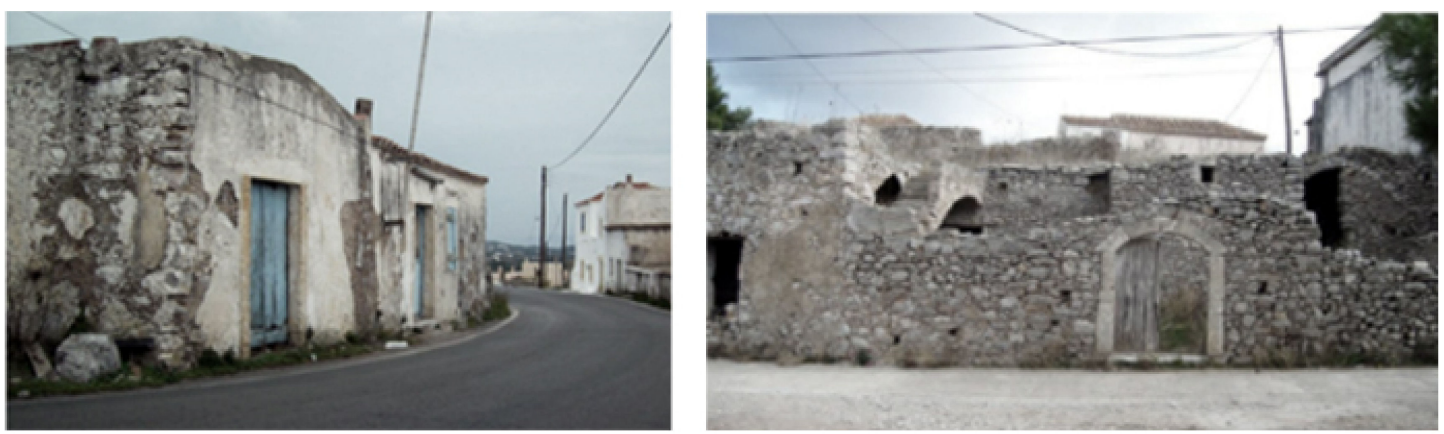

Figure 21. Aroniadika in Kythera. 


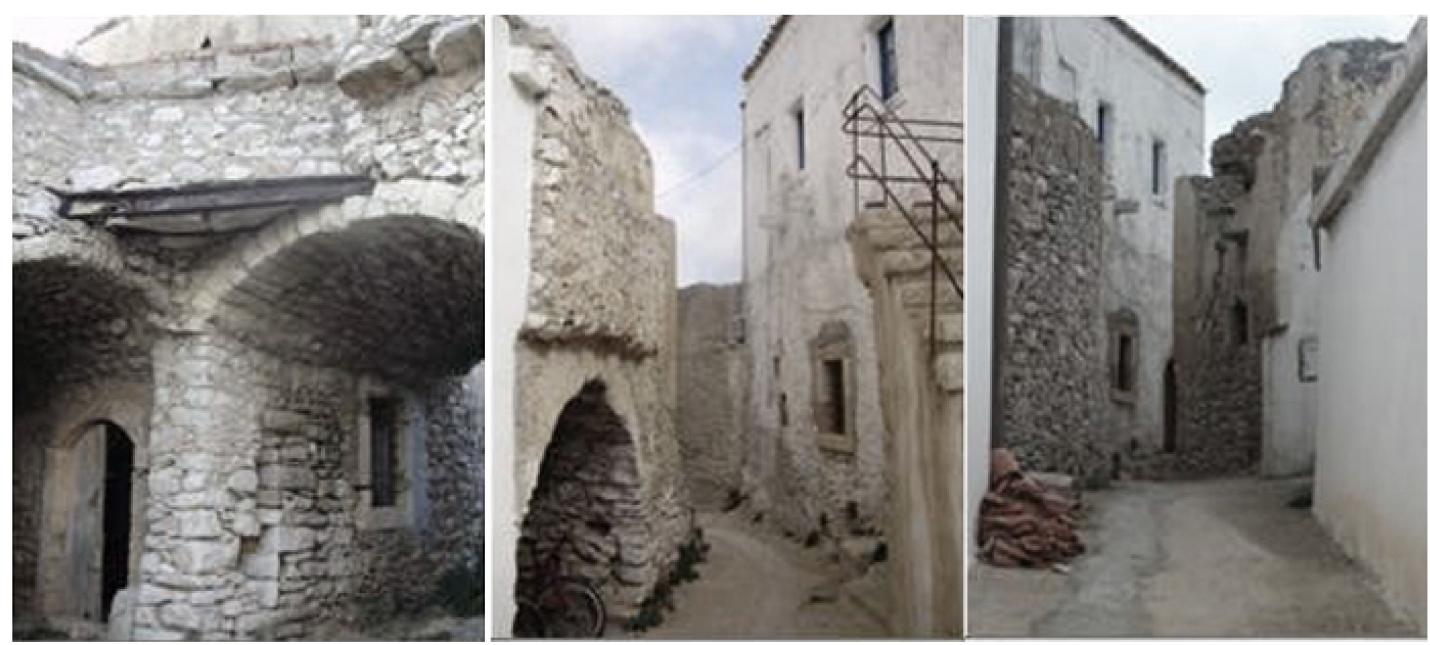

Figure 22. Kastritsianika in Kythera.

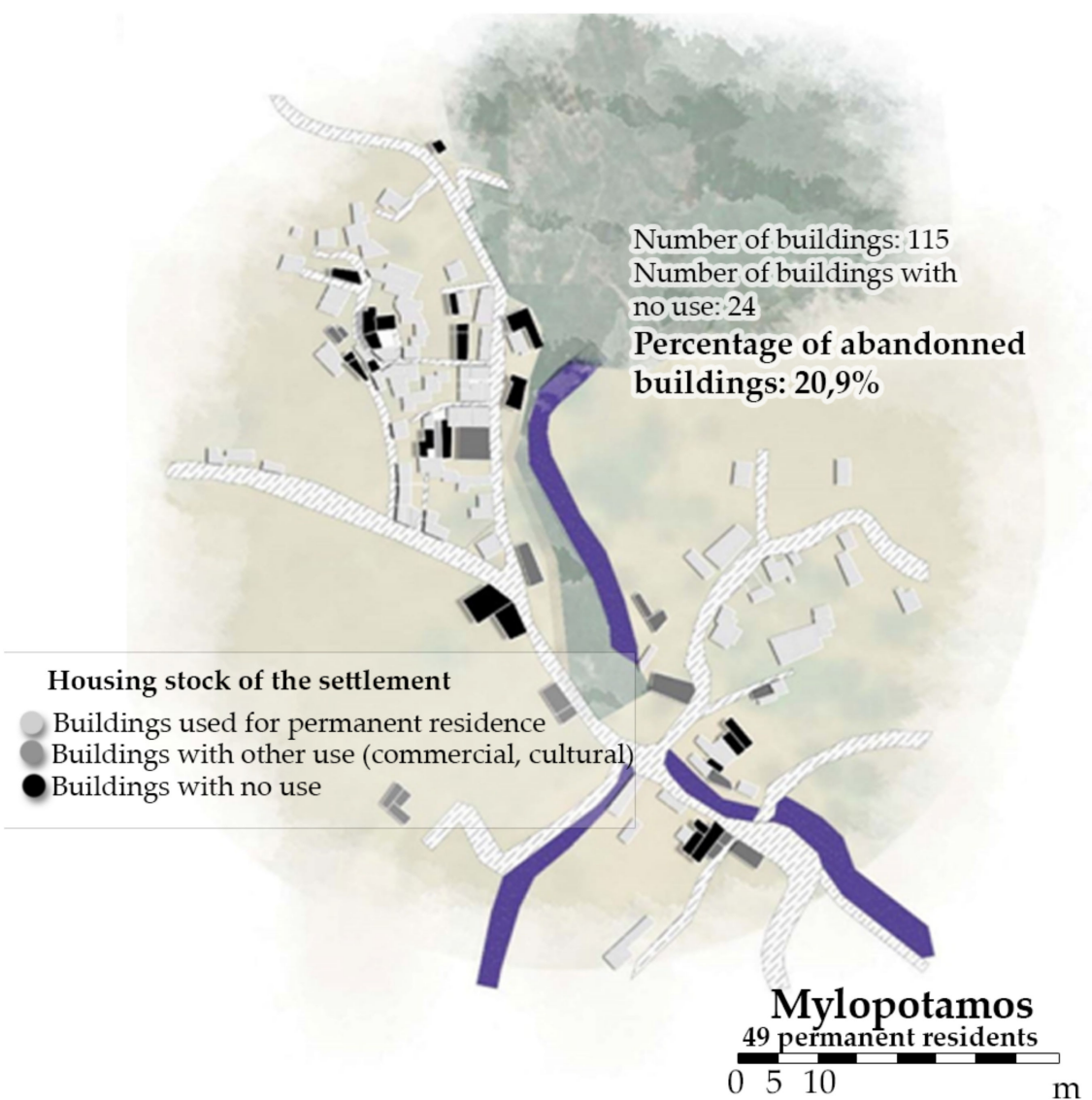

Figure 23. The housing stock of Mylopotamos. 
Number of buildings: 95

Number of buildings with

no use: 36

Percentage of abandonned buildings: $37,8 \%$

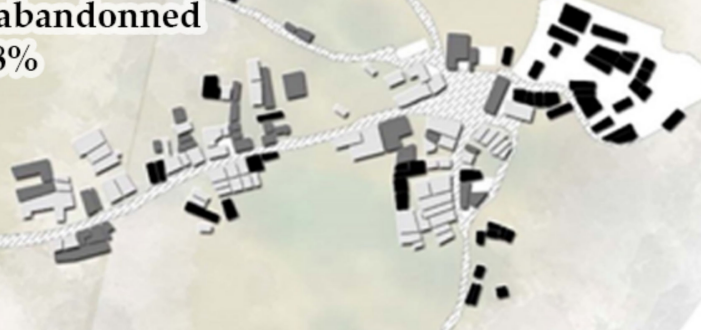

Housing stock of the settlement

Abandoned buildings

Buildings in need for preservation

Restored/ well preserved buildings

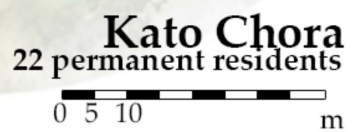

Figure 24. The housing stock of Kato Chora.

Number of buildings: 152

Number of buildings with

no use: 31

Percentage of abandonned buildings: $20,4 \%$
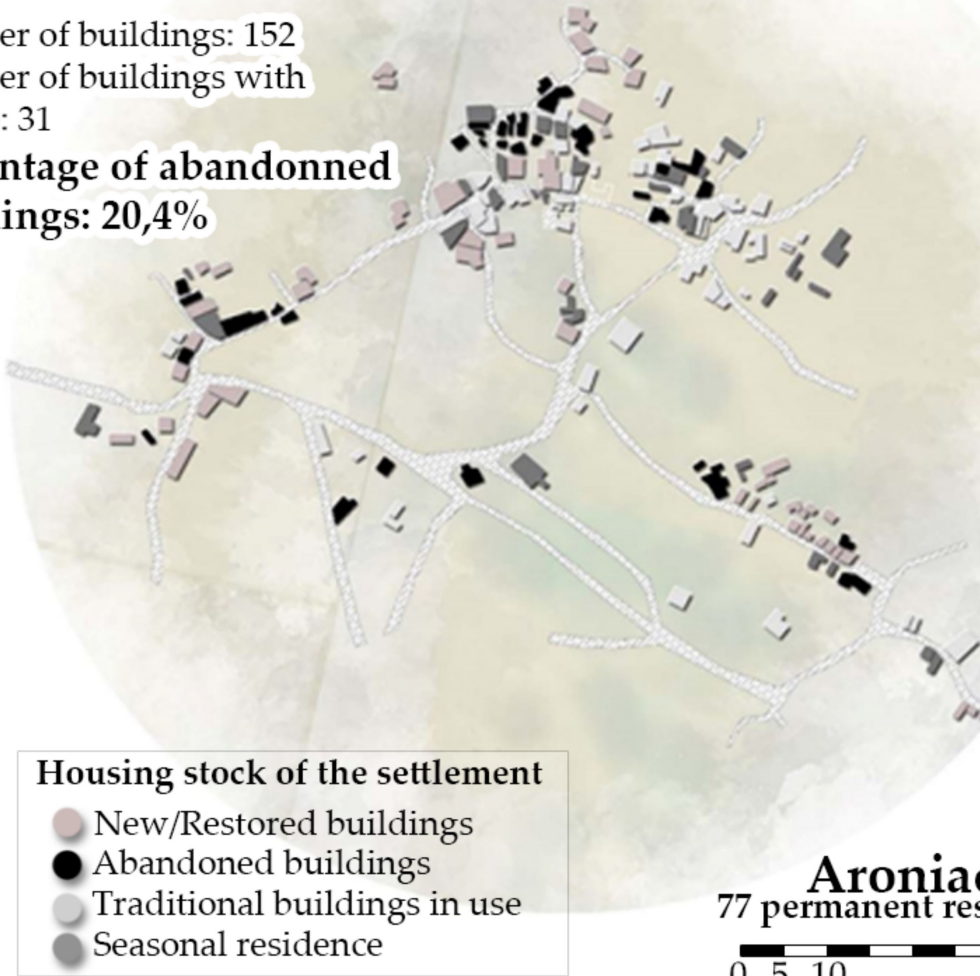

Housing stock of the settlement

New/Restored buildings

Seasonal residence

Aroniadika

77 permanent residents

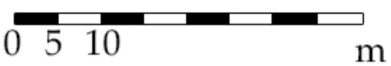

Figure 25. The housing stock of Aroniadika. 


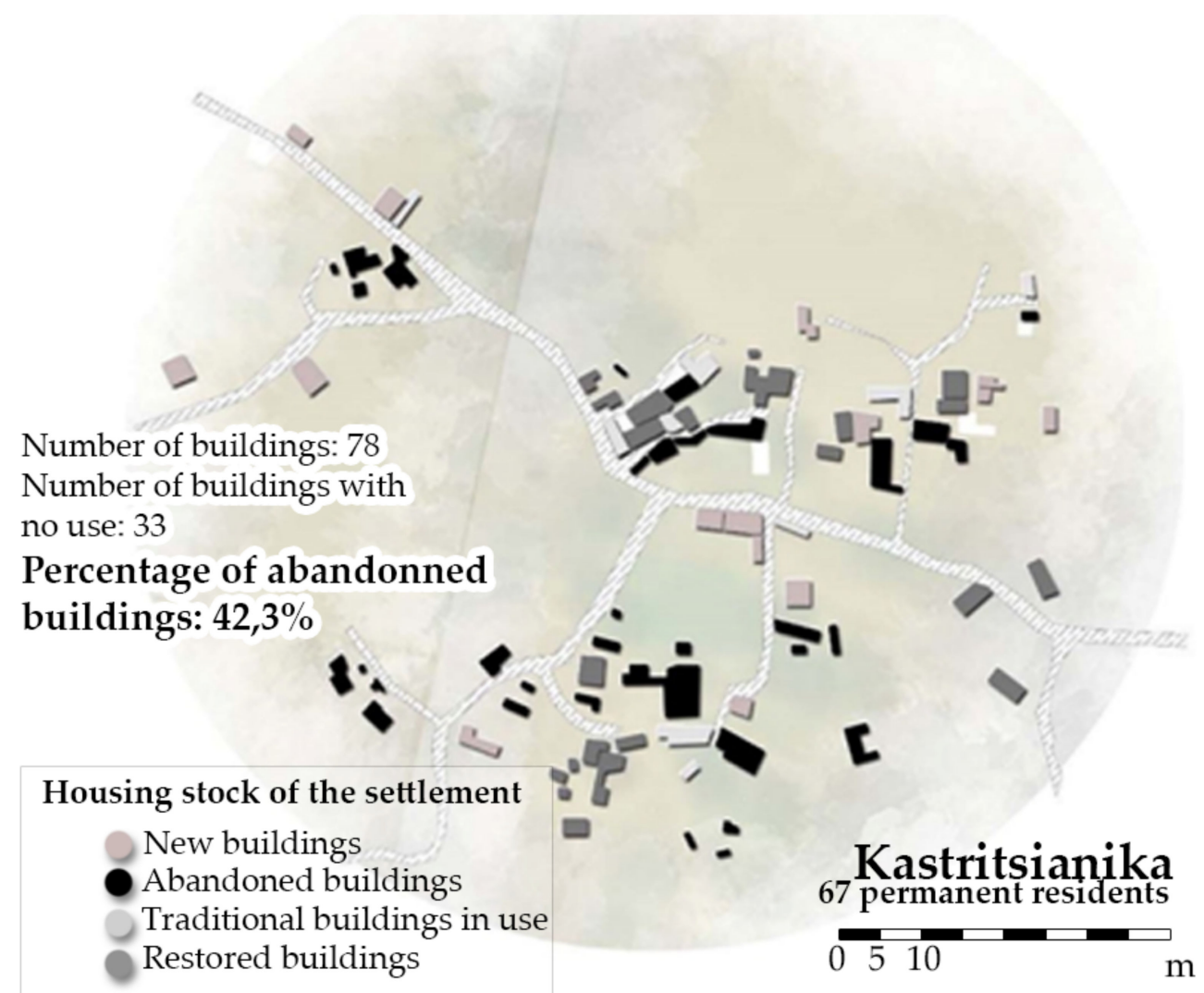

Figure 26. The housing stock of Kastritsianika.

\subsection{Proposal Scheme 3: Adaptive reuse of Mavrogiorgiannika, an Abandoned Neighborhood}

Mavrogiorgiannika (Figure 27) is an abandoned neighborhood in the village of Karavas, which is the most northern organized settlement of Kythera. This village used to and continues to be one of the main rural poles of the agriculture production of the island. It is set next to the main ravine of the island, home to the village's watermills and traditional irrigation canals [39]. Today, the residents of the village are socially active, promoting actions to preserve their traditional rural identity, the appealing natural environment and the architectural, cultural assets of the village. The Patrikios Agricultural School building, located in Karavas, belongs to the local community but unfortunately does not operate as such nowadays. The interest of the residents regarding their village, in combination with the fact that the northern part of Kythera is not as prominent as the southern one, set Karavas as one of this study's schemes. The proposal consists of different actions in order to reveal the village as an agricultural pole of interest for the whole island. The first of the schemes proposed in Karavas is the restoration of Mavrogiorgianika in order to operate as agricultural accommodation facilities. The neighborhood consists of 33 buildings (Figures 28 and 29), with a total of 68 rooms, addressing to potential visitors for different vacation scenarios. This proposal could both contribute to the preservation of the island's cultural assets in a financially viable way and also lay the foundation for a sustainable development model, respecting the local cultural identity and needs [51]. The revealing of the watermills and traditional irrigation canals could be combined with the above proposal, integrating the residents' existing efforts to preserve the traditional agriculture practices. Patrikios Agricultural School could serve as a modern institution for both residents and visitors regarding new and sustainable agricultural practices. According to this integrated plan, the village could preserve its special rural identity, but also create new job opportunities for its residents in order to achieve its economic prosperity. 


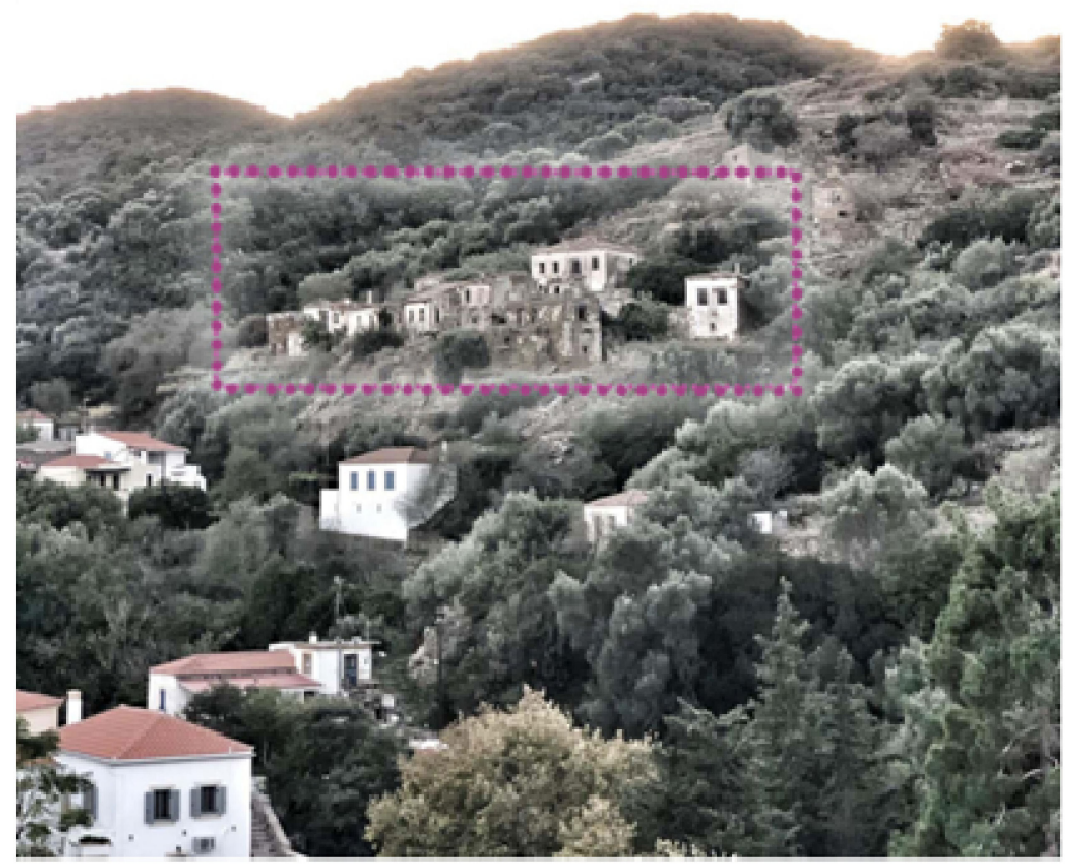

Figure 27. Mavrogiorgiannika in Karavas.
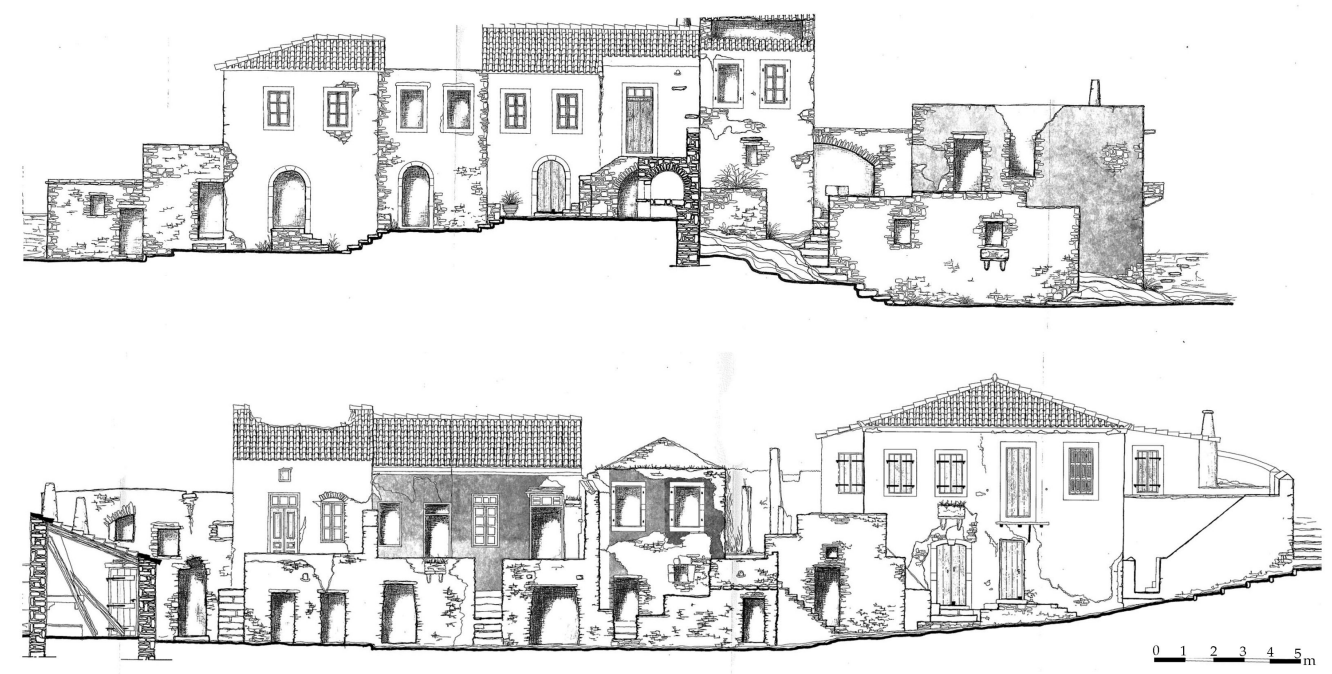

Figure 28. Facades of Mavrogiorgiannika neighborhood based on the drawings of C.Sougiannis.

The suggested intervention in Karavas consists of private investment since the buildings already belong to individual owners. The contribution of the local government is significant in this case in order to record and coordinate the individual owners, making sure that the residents of Karavas will be involved in the revealing project. In this case, apart from creating a new agricultural accommodation complex, the proposal suggested the combination of the traditional agricultural practices and everyday life with the offered tourism product of the island, educating both the residents and the visitors in the contemporary techniques of sustainable farming. The success of this project could lengthen the tourism period in the island, provide new job opportunities, and improve local production, providing environmental, social and economic benefits to the local community. The buildings of Mavrogiorgianika are private, abandoned by their owners a long time ago, so their ownership is unspecified. Thus, the proposed scheme for the area is private investment, combined with the necessary initiatives of the municipality and Eghorios Periousia. 


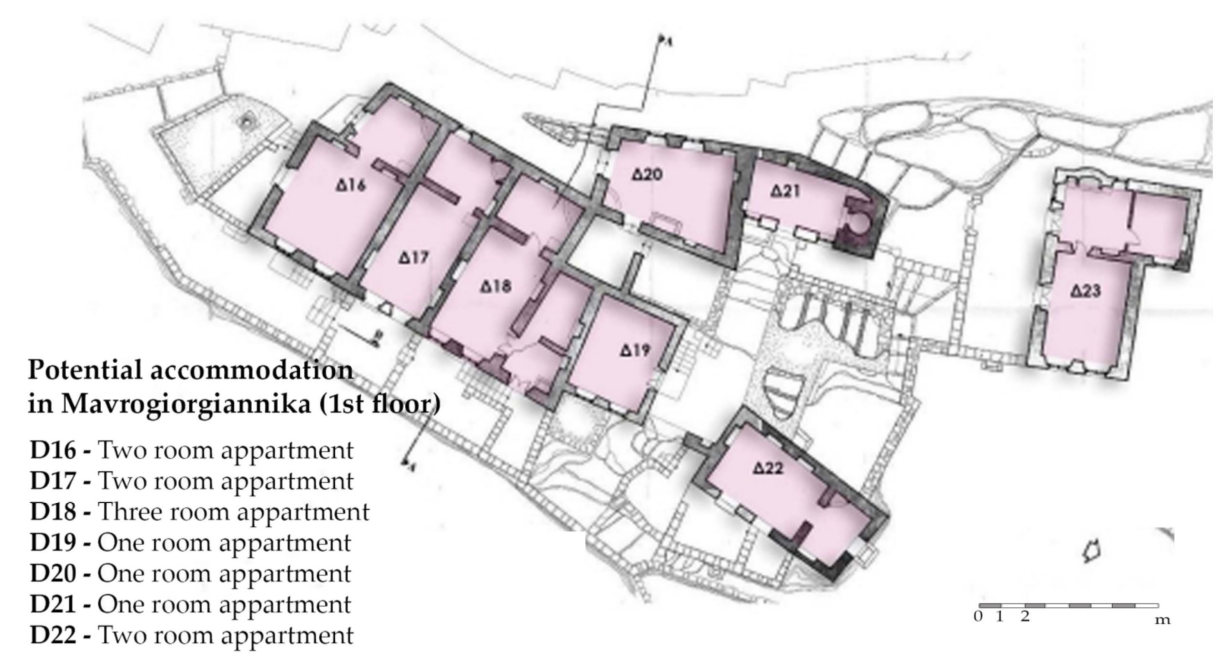

Figure 29. Potential accommodation in Mavrogiorgiannika (1st floor)—modified after C.Sougiannis drawings.

\section{Discussion}

Nowadays, the protection of architectural and cultural assets is directly related to their social address, sustainability and environment [7]. Remote areas could be particularly benefited by the preservation and revealing of their tangible and intangible cultural assets [9] in a way that permits the continuity of cultural heritage [3]. The revitalization of historical or traditional settlements in these areas could also be accomplished by cultural heritage adaptive reuse, providing physical, economic and social benefits [52,53]. Thus, sustainable cultural heritage management could be at the core of the overall local development plans, ensuring local social cohesion and local economic growth via tourism. For this purpose, the economic viability of cultural assets is crucial. Contemporary good practices of cultural heritage preservation and revealing [54-58] indicate that the choice of the management model of monuments' revealing is not unambiguous [20]. It is necessary to examine each case based on its special features and choose the model that is feasible to be applied [59] and, in any case, does not affect the integrity and the values of the cultural asset. The combination of management models (PPP, municipal management, private investment) could multiply the investment ability in the preservation of the cultural reserve $[60,61]$.

Tourism is directly related to both sustainable development and cultural heritage preservation and revealing. In Greece, the most widespread way of developing the local economy of an island is via tourism. This choice, depending on its implementation plan, could be either beneficial or destructive to the environment of its application [9]. An integrated plan of sustainable tourism development could serve as a regulating factor of the expected potential and threats. The financial benefits must be balanced with the well-being of the residents, the applied development schemes should not deplete the natural resources and the visitors' arrival period should not be the only one during which the permanent residents can be employed [62]. In rural, depopulated areas, agritourism, as a development model, could serve the goal of non exclusively seasonal tourism while creating additional economic opportunities for the locals who are mainly engaged in agriculture [63]. Additionally, this tourism model could set the area of its implementation as a distinct all-year destination, improving accessibility with the increase of ferry and airplane services $[64,65]$.

In these terms, cultural heritage preservation and revealing is an issue related to multiple factors. The integrated conservation approach aims to involve technical (structure of buildings), spatial (land use, public spaces, road network), social (needs of the local community), economic (tourism) and legal issues concerning cultural heritage preservation [66]. This interdisciplinary approach demands the detailed analysis of the study area, taking into consideration its special features per case [67] but also the communication with local stakeholders and residents in order to involve their needs in the suggested cultural 
preservation proposals. In this way, the educational values of cultural heritage can be revealed and widespread among the residents while creating a participatory framework referring to the preservation of cultural reserves [68].

In this spirit, aiming to outline the contribution of cultural assets' protection and revealing in sustainable development, this study is focused on Kythera, presenting a real case scenario. Kythera is a typical example of a remote, underdeveloped rural area [69,70], with an aging and decreasing population. Analysis of the study area has shown that the island's cultural reserve is diverse yet not sufficiently revealed. Additionally, there is a large, abandoned housing stock within the traditional settlements of Kythera, and the northern rural settlements of the island are underdeveloped. At the same time, the existence of Eghorios Periousia institute indicates the tradition of collective and participatory social organization in Kythera.

Apart from identifying Kythera's special features, the methodological approach followed in this research actively involved the human aspect of the island, trying to understand Kythera's residents and visitors needs by communicating with local government, stakeholders and using special questionnaires. According to the findings of Kythera's analysis, this study proposes three adaptive reuse schemes at different scales in order to capitalize the impact of cultural and environmental assets for the island's sustainable development (Figure 30). The proposals focused on the less promoted elements of the island's cultural heritage, combining their adaptive reuse with the rural tradition of Kythera: the English Schools, monuments of the less known period of Kythera's history, the British Rule; the four smaller traditional settlements of the island with large abandoned housing stock; and Mavrogiorgianika, an abandoned neighborhood in the less promoted northern part of Kythera.

The first proposal scheme, on individual building scale, refers to the adaptive reuse of English Schools with the aim to reveal them as monuments, but also to set them as landmarks of the island's tradition and culture. These buildings are confirmed to belong to Eghorios Periousia, so their exemplary preservation and the revealing process could encourage Kythera's residents to actively participate in the management of their intercommunal property. Their proposed management model is PPP so that the revenues from this intervention could fund other necessary actions of the municipality and Eghorios Periousia.

The second proposal scheme, regarding individual buildings within the scale of a traditional settlement, refers to the adaptive reuse of the abandoned housing stock in the four smaller traditional settlements of the island. In this case, the goal is, on the one hand, to reveal the less known settlements of the island (Mylopotamos and Kato Chora) with the reuse of their housing stock for tourism uses, and on the other hand, to reuse the abandoned buildings in order to create affordable permanent residence accommodation (Aroniadika, Kastritsianika). This scheme's management is proposed to be municipal, utilizing some of the English Schools' profits.

The third proposal scheme, on a neighborhood scale, refers to the adaptive reuse of the abandoned neighborhood Mavrogiorgiannika in Karavas, (the most northern settlement of the island), as agritourism accommodation. Karavas is a settlement with rural tradition, and its residents are mainly occupied in agriculture. The aim of this proposal is to set the less promoted northern part of Kythera in the center of the island's agritourism development.

Each one of the proposal schemes aims to address a different aspect of Kythera's sustainability and cultural heritage preservation and revealing. Developing an agritourism model in Kythera could provide new economic opportunities to the local community, encouraging young people to stay and work on the island. The adaptive reuse of Kythera's cultural assets in this framework could set local heritage as a pillar of the island's sustainable development. 


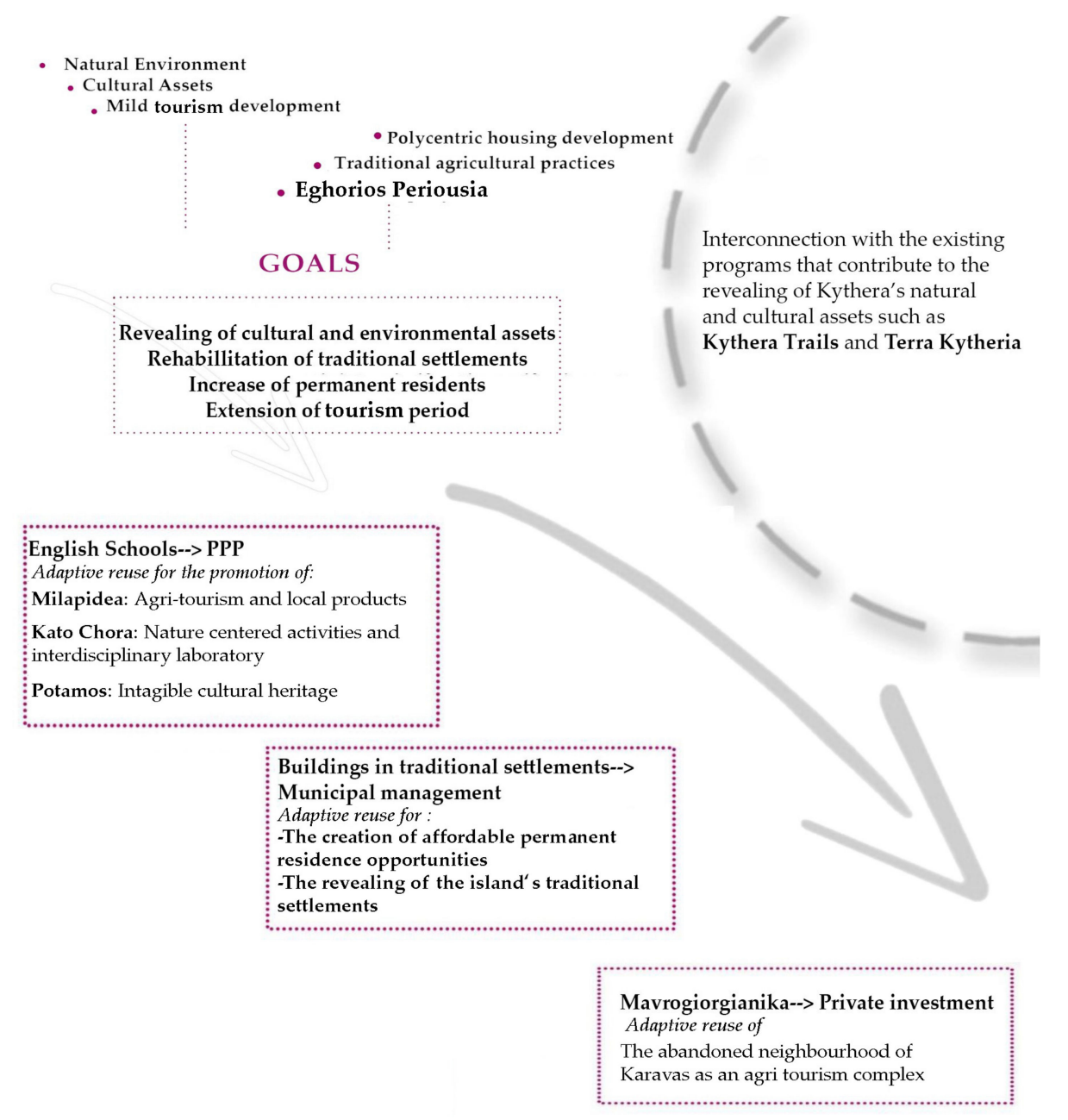

Figure 30. Flowchart summarizing the proposal schemes for Kythera.

\section{Conclusions}

In this study, the sustainable development of the remote Greek island of Kythera was examined based on the preservation of its cultural assets. The combination of methods in the analysis of the study area (research in local archives, communication with local government and stakeholders, questionnaires addressing Kythera's residents and visitors) provided an all-encompassing view of the contemporary profile of Kythera, future prospects, and issues to be addressed. Subsequently, the three presented proposal schemes outlined that an adaptive reuse concept can be applied on different scales, revitalizing the local communities. In order to preserve the cultural reserve while configuring favorable living conditions for the residents, it is important to balance desired economic growth with sustainable heritage management. Focus on a specific study area allowed for the island's special features to emerge in terms of social organization (Eghorios Periousia), cultural assets (English Schools) and rural tradition (Patrikios Agricultural School in Karavas), thus directing the suggested schemes. Future research related to this study could include the aspect of ownership for the island's housing stock; this research will be possible in the near future when the detailed Land Registry of Kythera will be available. Additionally, the case study of Kythera could be examined in relation to other islands of the Mediterranean Basin, with a similar history and demography, thus enabling the development of a general methodology for their sustainable development.

Author Contributions: A.M. conceived the research; A.M. and E.T.D. supervised the overall writing of the paper; A.V. elaborated the results for her Master Thesis entitled "Sustainable preservation and revealing of Kythera's traditional settlements and cultural assets in terms of circular economy" under 
the supervision of A.M., C.C. and E.T.D.; C.C. and A.V. performed the historical and architectural analysis; A.V. designed the questionnaire, studied the local archives and illustrated the paper. E.T.D. provided the methodological approach of this study; E.T.D. and A.V. wrote, reviewed and edited the paper. All authors have read and agreed to the published version of the manuscript.

Funding: This research received no external funding.

Data Availability Statement: Not applicable.

Acknowledgments: The authors would like to acknowledge the great support of C. Sougiannis, Vice Mayor of Kythera and architect, who provided useful information and the rare sketches of Mavrogiorgianika. The authors acknowledge the collaboration of Ch. Sofiou, the rural, surveying and geoinformatics engineer of the Eghorios Periousia in Kythera. In addition, the authors would like to thank the representatives of the Municipality of Kythera and the Kytherian Institute for Culture and Development for sharing valuable information. Finally, this paper would not be completed without the useful thoughts and information of D. Mola and A. Maratos, architects who work and live in Kythera, in addition to E. Harou and M. Kalligeros, local journalists.

Conflicts of Interest: The authors declare no conflict of interest.

\section{References}

1. Mallouhou-Tuffano, F. Protection \& Management of Monuments-Historical and Theoretical Approaches; Association of Greek Academic Libraries: Athens, Greece, 2015; pp. 12-23, ISBN 978-960-603-377-3.

2. Yiannakou, A.; Eppas, D.; Zeka, D. Spatial Interactions between the Settlement Network, Natural Landscape and Zones of Economic Activities: A Case Study in a Greek Region. Sustainability 2017, 9, 1715. [CrossRef]

3. Wijesuriya, G. Annex 1: Living Heritage: A Summary. Rome: ICCROM. 2015. Available online: https://www.iccrom.org/ wpcontent/uploads/PCA_Annexe-1.pdf (accessed on 8 November 2021).

4. Poulios, I. Discussing strategy in heritage conservation: Living heritage approach as an example of strategic innovation. J. Cult. Herit. Manag. Sustain. Dev. 2014, 4, 16-34. [CrossRef]

5. López-Sanz, J.M.; Penelas-Leguía, A.; Gutiérrez-Rodríguez, P.; Cuesta-Valiño, P. Sustainable Development and Rural Tourism in Depopulated Areas. Land 2021, 10, 985. [CrossRef]

6. Khalaf, R. World Heritage on the Move: Abandoning the Assessment of Authenticity to Meet the Challenges of the Twenty-First Century. Heritage 2021, 4, 371-386. [CrossRef]

7. Guzman, P.; Roders, A.P.; Colenbrander, B. Measuring links between cultural heritage management and sustainable urban development: An overview of global monitoring tools. Cities 2017, 60, 192-201. [CrossRef]

8. Gravanguolo, A.; De Angelis, R.; Iodice, S. Circular Economy Strategies in the Historic Built Environment: Cultural Heritage Adaptive Reuse. In Proceedings of the 18th Annual STS Conference Graz 2019. Critical Issues in Science, Technology and Society Studies, Graz, Austria, 6-7 May 2019. [CrossRef]

9. ESPON. In The Development of the Islands-European Islands and Cohesion Policy (EUROISLANDS); Final Report; European Comission: Luxemburg, 2013. Available online: https://www.espon.eu/programme/espon/espon-2020-cooperation-programme (accessed on 11 October 2021).

10. Koutsi, D.; Stratigea, A. Sustainable and Resilient Management of Underwater Cultural Heritage (UCH) in Remote Mediterranean Islands: A Methodological Framework. Heritage 2021, 4, 3469-3496. [CrossRef]

11. Ratification of Agreement for the Protection of Architectural Heritage (Law 2039/1992, Official Gazette of the Greek Government No 61/13.04.1992). Available online: https:/ / www.e-nomothesia.gr/kat-arxaiotites/nomos-2039-1992-phek-61a-13-4-1992.html (accessed on 11 October 2021).

12. Protection of Antiquities and Cultural Heritage (Law 3028/2002, Official Gazette of the Greek Government No 153/28.06.2003). Available online: https:/ / www.e-nomothesia.gr/kat-arxaiotites/n-3028-2002.html (accessed on 11 October 2021).

13. Vyzantiadou, M.M.; Selevista, M. Protection of Cultural Heritage in Thessaloniki: A Review of Designation Actions. Heritage 2019, 2, 717-731. [CrossRef]

14. He, Y.-F.; Chen, C.-P.; Chou, R.-J. The Key Factors Influencing Safety Analysis for Traditional Settlement Landscape. Sustainability 2019, 11, 3431. [CrossRef]

15. Council of Europe. European Landscape Convention, European Treaty Series-No. 176, Strasbourg, France, 20 October 2000. p. 7. Available online: https:/ /rm.coe.int/1680080621 (accessed on 11 October 2021).

16. COE. Framework Convention on the Value of Cultural Heritage for Society in Faro; Council of Europe Treaty Series-No. 199, Faro, Portugal, 27 October 2005. Available online: https:/ / www.coe.int/en/web/culture-and-heritage/faro-convention (accessed on 11 October 2021).

17. UCLG. xecutive Bureau. Culture: Fourth Pillar of Sustainable Development, in Draft Proposal for Approval of the UCLG Executive Bureau; World Summit of Local and Regional Leaders-3rd World Congress of UCLG, Mexico, 17 November 2010. Available online: https:/ / www.agenda21culture.net/sites/default/files / files/documents/en/zz_culture4pillarsd_eng.pdf (accessed on 11 October 2021). 
18. Potts, A. Climate Heritage Network, European Cultural Heritage Green Paper; The Hague \& Brussels 2021. Available online: https:/ /issuu.com/europanostra/docs/20210322-european_cultural_heritage_green_paper_fu (accessed on 20 November 2021).

19. Pickard, R. Funding the Architectural Heritage: A Guide to Policies and Examples; Council of Europe Publications: Strasbourg, France, 2009; pp. 12-20, ISBN 9287164983.

20. Perry, J.; Gordon, I.J. Adaptive Heritage: Is This Creative Thinking or Abandoning Our Values? Climate 2021, 9, 128. [CrossRef]

21. Sala, S.; Ciuffo, B.; Nijkamp, P. A systemic framework for sustainability assessment. Ecol. Econ. 2015, 119, 314-325. [CrossRef]

22. Moropoulou, A.; Delegou, E.T. Innovative technologies and strategic planning methodology for assessing and decision making concerning preservation and management of historic cities. In Proceedings of the 7th International Symposium of the Organization of World Heritage Cities, Rhodes, Greece, 23-26 September 2003.

23. Roszczynska-Kurasinska, M.; Domaradzka, A.; Wnuk, A.; Oleksy, T. Intrinsic Value and Perceived Essentialism of Culture Heritage Sites as Tools for Planning Interventions. Sustainability 2021, 13, 5078. [CrossRef]

24. Oikonomopoulou, E.; Delegou, E.; Sayas, J.; Moropoulou, A. An innovative approach to the protection of cultural heritage: The case of cultural routes in Chios Island, Greece. J. Archaeol. Sci. Rep. 2017, 14, 742-757. [CrossRef]

25. Foster, G. Circular economy strategies for adaptive reuse of cultural heritage buildings to reduce environmental impacts. Resour. Conserv. Recycl. 2020, 152, 104507. [CrossRef]

26. CLIC Project. Available online: https://www.clicproject.eu/ (accessed on 5 October 2021).

27. Baker, H.; Moncaster, A.; Al-Tabbaa, A. Decision-making for the demolition or adaptation of buildings. Proc. Inst. Civ. Eng. Forensic Eng. 2017, 170, 144-156. [CrossRef]

28. Gravagnuolo, A.; Micheletti, S.; Bosone, M. A Participatory Approach for "Circular" Adaptive Reuse of Cultural Heritage. Building a Heritage Community in Salerno, Italy. Sustainability 2021, 13, 4812. [CrossRef]

29. Bandarin, F.; van Oers, R. The Historic Urban Landscape: Managing Heritage in an Urban Century; Wiley Blackwell: Chichester, UK; Hoboken, NJ, USA, 2012; ISBN 978-0-470-65574-0.

30. Radoine, H. Urban conservation of Fez-Medina. Global Urban Dev. 2008, 4. Available online: https://www.globalurban.org/ GUDMag08Vol4Iss1/Radoine.htm (accessed on 11 October 2021).

31. MedINA INCREAte Project Website. Available online: https://increate.med-ina.org/el/page/published-project/5 (accessed on 20 November 2021).

32. Georgiadis, N.M.; Melissourgos, Y.; Dodouras, S.; Lyratzaki, I.; Dimitropoulos, G.; Foutri, A.; Mordechai, L.; Zafeiriou, R.; Papayannis, T. Reconnecting Nature and Culture-The INCREAte Approach and Its Practical Implementation in the Island of Kythera. Heritage 2019, 2, 1630-1639. [CrossRef]

33. Dodouras, S.; Liratzaki, E. Recording and Evaluation of the Cultural Characteristics of Kythera and Antikythera; MedINA: Athens, Greece, 2017; pp. 9-14, 72-76. Available online: https://med-ina.org/wp-content/uploads/2021/01/Kythera-Cultural-RapidAssessment.pdf (accessed on 20 November 2021).

34. Bury, J.B.; Meiggs, R. A History of Greece, Greek Translation; Kardamitsa Publications: Athens, Greece, 2011; pp. 84, 420-423, 436, 441, ISBN 0333154932.

35. Koukkou, E. History of the Ionian Islands from 1797 until the British Occupation; Papadima Publications: Athens, Greece, 1983; pp. 16, 32-40, ISBN 9789602064504.

36. Filippidis, D. Greek Traditional Architecture-Kythera; Melissa Publicalions: Athens, Greece, 1983; pp. 3-24, ISBN 9602041366.

37. Eghorios Periousia Website. Available online: https://www.eghorios.gr/ (accessed on 20 November 2021).

38. Municipality of Kythera. Strategic Planning of the Municipality of Kythira. 2011, pp. 50-54. Available online: http:/ / kythira.gr/ oldsite/downloads/Strat_sxed.pdf (accessed on 20 November 2021).

39. Sougiannis, C.H. Principles of protection of modern monuments-The example of the traditional settlement Mavrogiorgiannika in Karavas, Kythera. In Proceedings of the 1st International Conference Myth \& Reality, Kythera, Greece, 20-24 September 2000.

40. Caradimas, C.A. Analysing and Understanding the Construction of Vernacular Buildings at the National Technical University of Athens. Arch. Urban Plan. 2013, 8, 28. [CrossRef]

41. Kasimatis, G. The Institution of Domestic Wealth Board. In The Union of the Ionian Islands with Greece; Greek Parliament Publications: Athens, Greece, 2005; pp. 300-324, ISBN 978-960-560-082-2.

42. Leontsini, E. Domestic Wealth Board of Kythera and Antikythera-History and Politics. In Kythera: Myths and Reallity; Free Open University of Kythera Publications: Athens, Greece, 2003; pp. 241-252, ISBN 9789608774223.

43. Municipality of Kythera. Sustainable Energy Action Plan; Municipality of Kythera: Kythera, Greece, 2016; pp. 25-30. Available online: https:/ / mycovenant.eumayors.eu/docs/seap/22050_1490862892.pdf (accessed on 20 November 2021).

44. Kythera Trails Website. Available online: https:// kytheratrails.gr/ (accessed on 20 November 2021).

45. Kythera Institution of Culture and Development Homepage (KIPA). Available online: Kipa-foundation.org (accessed on 11 October 2021).

46. Leader/CLLD Website. Available online: https:/ / ead.gr/information/leader-clld/ (accessed on 20 November 2021).

47. Cultural Routes of the Council of Europe Programme. Available online: https://www.coe.int/en/web/cultural-routes (accessed on 8 November 2021).

48. Karavasili, M.; Mikelakis, E. Cultural Routes, towards an interpretation of the "cultural landscape" with de a development potential. Archeol. Arts 1999, 71, 82-86. 
49. Oikonomopoulou, E.; Delegou, E.T.; Vesic, N.; Moropoulou, A. Innovative Cross-Cultural Approach for the Emergence of Common Cultural Heritage in Greece and Serbia a Comparative Study of the 13th-14th Century Orthodox Monasteries, Scienza e Beni Culturali XXVII; Arcadia Ricerche Editore: Padova, Italy, 2011; pp. 311-322.

50. Moropoulou, A.; Lampropoulos, K.; Vythoulka, A. The Riverside Roads of Culture as a Tool for the Development of Aitoloakarnania. Heritage 2021, 4, 3823-3847. [CrossRef]

51. Bastakis, C.; Buhalis, D.; Butler, R. The perception of small and medium sized tourism accommodation providers on the impacts of the tour operators' power in Eastern Mediterranean. Tour. Manag. 2004, 25, 151-170. [CrossRef]

52. Vehbi, B.O.; Hoşkara, Ş.Ö. A Model for Measuring the Sustainability Level of Historic Urban Quarters. Eur. Plan. Stud. 2009, 17, 715-739. [CrossRef]

53. Koutsi, D.; Stratigea, A. Unburying Hidden Land and Maritime Cultural Potential of Small Islands in the Mediterranean for Tracking Heritage-Led Local Development Paths. Heritage 2019, 2, 938-966. [CrossRef]

54. Harrouni, K. Sustainable urban conservation of historical cities come back to thirty five years of observation in Medina Fez, Marocco. In Proceedings of the ICOMOS 19th General Assembly and Scientific Symposium "Heritage and Democracy", New Delhi, India, 13-14 December 2017. Available online: https://openarchive.icomos.org/id/eprint/1946/ (accessed on 20 November 2021).

55. Labadi, S.; Giliberto, F.; Rosetti, I.; Shetabi, L.; Yildirim, E. Heritage and the Sustainable Development Goals: Policy Guidance for Heritage and Development Actors; ICOMOS: Paris, France, 2021; pp. 22-25. Available online: https://www.icomos.org/images/ DOCUMENTS/Secretariat/2021/SDG/ICOMOS_SDGs_Policy_Guidance_2021.pdf (accessed on 11 October 2021).

56. Aldeia da Pedralva Webpage. Available online: https://www.aldeiadapedralva.com/en/ (accessed on 20 November 2021).

57. Agapito, D.; Mendes, J.; Valle, P.O. The rural village as an open door to nature-based tourism in Portugal: The Aldeia da Pedralva case. Tourism Rev. 2012, 60, 325-338.

58. Redock Project Webpage. Available online: https:/ / www.redock.org/projects/project-spain/ (accessed on 11 October 2021).

59. Henche, B.; Salvaj, E.; Cuesta-Valiño, P. A Sustainable Management Model for Cultural Creative Tourism Ecosystems. Sustainability 2020, 12, 9554. [CrossRef]

60. Mikić, H. Sustainable cultural heritage management in creative economy: Guidelines for local decision makers and stakeholders. In Cultural Heritage E Creative Industries; Rypkema, D., Mikić, H., Eds.; Creative Economy Group Foundation: Belgrad, Serbia, 2015; pp. 9-24, ISBN 978-86-88981-06-4.

61. Nižić, M.; Ivanović, S.; Drpić, D. Challenges to Sustainable Development in Island Tourism. South East Eur. J. Econ. Bus. 2010, 5, 43-53. [CrossRef]

62. Kouri, M. Merging Culture and Tourism in Greece: An Unholy Alliance or an Opportunity to Update the Country's Cultural Policy? J. Arts Manag. Law Soc. 2012, 42, 63-78. [CrossRef]

63. Scuttari, A.; Della Lucia, M.; Martini, U. Integrated planning for sustainable tourism and mobility. A tourism traffic analysis in Italy's South Tyrol region. J. Sustain. Tour. 2013, 21, 614-637. [CrossRef]

64. Zhang, H.; Wu, Y.; Buhalis, D. A model of perceived image, memorable tourism experiences and revisit intention. J. Destin. Mark. Manag. 2018, 8, 326-336. [CrossRef]

65. Michael, A.S.; Smriti, D.; Sanjay, N.; Schuett, M.A.; Dahal, S.; Nepal, S. Local perspectives on benefits of an integrated conservation and development project: The Annapurna conservation area in Nepal. Int. J. Biodivers. Conserv. 2016, 8, 138-146. [CrossRef]

66. Yuceer, H.; Vehbi, B.O. Adaptive Reuse of Carob Warehouses in Northern Cyprus. Open House Int. 2014, 39, 65-77. [CrossRef]

67. Saifi, Y. Role of universities in preserving cultural heritage in areas of conflict. Int. J. Cult. Policy 2020, 1-15. [CrossRef]

68. Koutsouris, A. Social learning and sustainable tourism development; local quality conventions in tourism: A Greek case study. J. Sustain. Tour. 2009, 17, 567-581. [CrossRef]

69. Tsartas, P. Tourism Development in Greek Insular and Coastal Areas: Sociocultural Changes and Crucial Policy Issues. J. Sustain. Tour. 2003, 11, 116-132. [CrossRef]

70. Ciolac, R.; Adamov, T.; Iancu, T.; Popescu, G.; Lile, R.; Rujescu, C.; Marin, D. Agritourism-A Sustainable Development Factor for Improving the 'Health' of Rural Settlements. Case Study Apuseni Mountains Area. Sustainability 2019, 11, 1467. [CrossRef] 